Trinity University

Digital Commons@ Trinity

Geosciences Faculty Research

Geosciences Department

2002

Thermochronological Constraints on the Timing and Magnitude of Miocene and Pliocene Extension in the Central Wassuk Range, Western Nevada

D. F. Stockli

Benjamin E. Surpless

Trinity University, bsurples@trinity.edu

T. A. Dumitru

Follow this and additional works at: https://digitalcommons.trinity.edu/geo_faculty

Part of the Earth Sciences Commons

\title{
Repository Citation
}

Stockli, D.F., Surpless, B.E., \& Dumitru, T.A. (2002). Thermochronological constraints on the timing and magnitude of miocene and pliocene extension in the central Wassuk range, western Nevada. Tectonics, 21(4), 10-1-10-19. doi:10.1029/2001TC001295

This Article is brought to you for free and open access by the Geosciences Department at Digital Commons @ Trinity. It has been accepted for inclusion in Geosciences Faculty Research by an authorized administrator of Digital Commons @ Trinity. For more information, please contact jcostanz@trinity.edu. 


\title{
Thermochronological constraints on the timing and magnitude of Miocene and Pliocene extension in the central Wassuk Range, western Nevada
}

\author{
Daniel F. Stockli, ${ }^{1}$ Benjamin E. Surpless, and Trevor A. Dumitru \\ Department of Geological and Environmental Sciences, Stanford University, Stanford, California, USA
}

Kenneth A. Farley

Division of Geological and Planetary Sciences, California Institute of Technology, Pasadena, California, USA

Received 23 April 2001; revised 5 February 2002; accepted 27 February 2002; published 8 August 2002

[1] Apatite fission track and (U-Th)/He thermochronological data provide new constraints on the timing of faulting and exhumation of the Wassuk Range, western Nevada, where east dipping normal faults have accommodated large-magnitude ENE-WSW oriented extension. Extensional deformation has resulted in the exhumation of structurally coherent fault blocks that expose sections of preextensional mostly granitic upper crust in the Grey Hills and central Wassuk Range. These fault blocks display westward tilts of $\sim 60^{\circ}$ and expose preextensional paleodepths of up to $\sim 8.5 \mathrm{~km}$, based on the structural reconstruction of tilted preextensional Tertiary andesite flows that unconformably overlie Mesozoic basement rocks. Apatite fission track and (U-Th)/He thermochronological data from the fault blocks constrain the onset of rapid footwall exhumation at $\sim 15$ Ma. Fission track modeling results indicate rapid fault block exhumation occurred between $\sim 15$ and $12 \mathrm{Ma}$, which is in agreement with Miocene volcanic rocks that bracket the tilting history. In addition, fission track and (U-Th)/He data suggest reduced rates of cooling following major extension, as well as renewed cooling related to active, high-angle faulting along the present-day range front starting at $\sim 4 \mathrm{Ma}$. Thermochronological data from structurally restored fault blocks indicate a preextensional Miocene geothermal gradient of $27^{\circ} \pm 5^{\circ} \mathrm{C} / \mathrm{km}$. The thermochronological constraints on the timing of extensional faulting and the eruptive history in the Wassuk Range imply a model for extension where crustal heating and volcanism precede the onset of rapid large magnitude extension, and where synextensional magmatism is suppressed during the highest rates of extension. INDEX TERMS: 8109

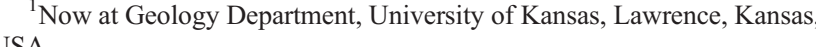

Copyright 2002 by the American Geophysical Union. 0278-7407/02/2001TC001295
}

Tectonophysics: Continental tectonics - extensional (0905); 1035 Geochemistry: Geochronology; 8015 Structural Geology: Local crustal structure; 9604 Information Related to Geologic Time: Cenozoic; KEYWORDS: Basin and Range, Walker Lane Belt, Wassuk Range, extension, thermochronology

\section{Introduction}

[2] In many localities throughout the Basin and Range province, large-magnitude extension has exhumed and exposed many kilometers thick structural sections of the preextensional upper crust. Where structurally coherent, these tilted fault blocks provide an opportunity to study the structural and thermal history of the upper crust, especially at the onset of major extension [e.g., Foster et al., 1990, 1991; Fitzgerald et al., 1991; Gans et al., 1991; Howard and Foster, 1996; Miller et al., 1999; Foster and John, 1999; Stockli et al., 2000]. Several of these cited studies demonstrated geothermal gradients at the onset of extension in the Basin and Range province that vary from values as low as $\sim 15^{\circ} \mathrm{C} / \mathrm{km}$ [Howard and Foster, 1996; Stockli, 1999; Stockli et al., 2000] to as high as $50^{\circ} \pm 20^{\circ} \mathrm{C} /$ $\mathrm{km}$ [Foster et al., 1991]. These variations in the thermal structure of the crust have been hypothesized to correlate with the presence or absence of synextensional magmatism or with distance from metamorphic core complexes [Howard and Foster, 1996], but the exact role of heat in crustal weakening and the initiation of extension remains an intriguing question that is not yet answered.

[3] Along the western margin of the northern Basin and Range province at the latitude of Lake Tahoe (Figure 1), the central Wassuk Range area exposes several essentially intact, tilted fault blocks composed almost entirely of quartz monzonite of the Mesozoic Sierran magmatic arc [Dilles, 1992; Dilles and Gans, 1995; Surpless, 1999] (Figure 2). These fault blocks expose up to $\sim 8.5 \mathrm{~km}$ of the preextensional upper crust as determined by measuring down-section from a preserved preextensional Tertiary basal unconformity which is tilted $\sim 60^{\circ}$ westward [Surpless, 1999]. Apatite fission track and (U-Th)/He thermochronological data from preextensional paleodepth transects across two major blocks in the central Wassuk Range area allow us to assess the timing of footwall cooling related to extensional deforma- 


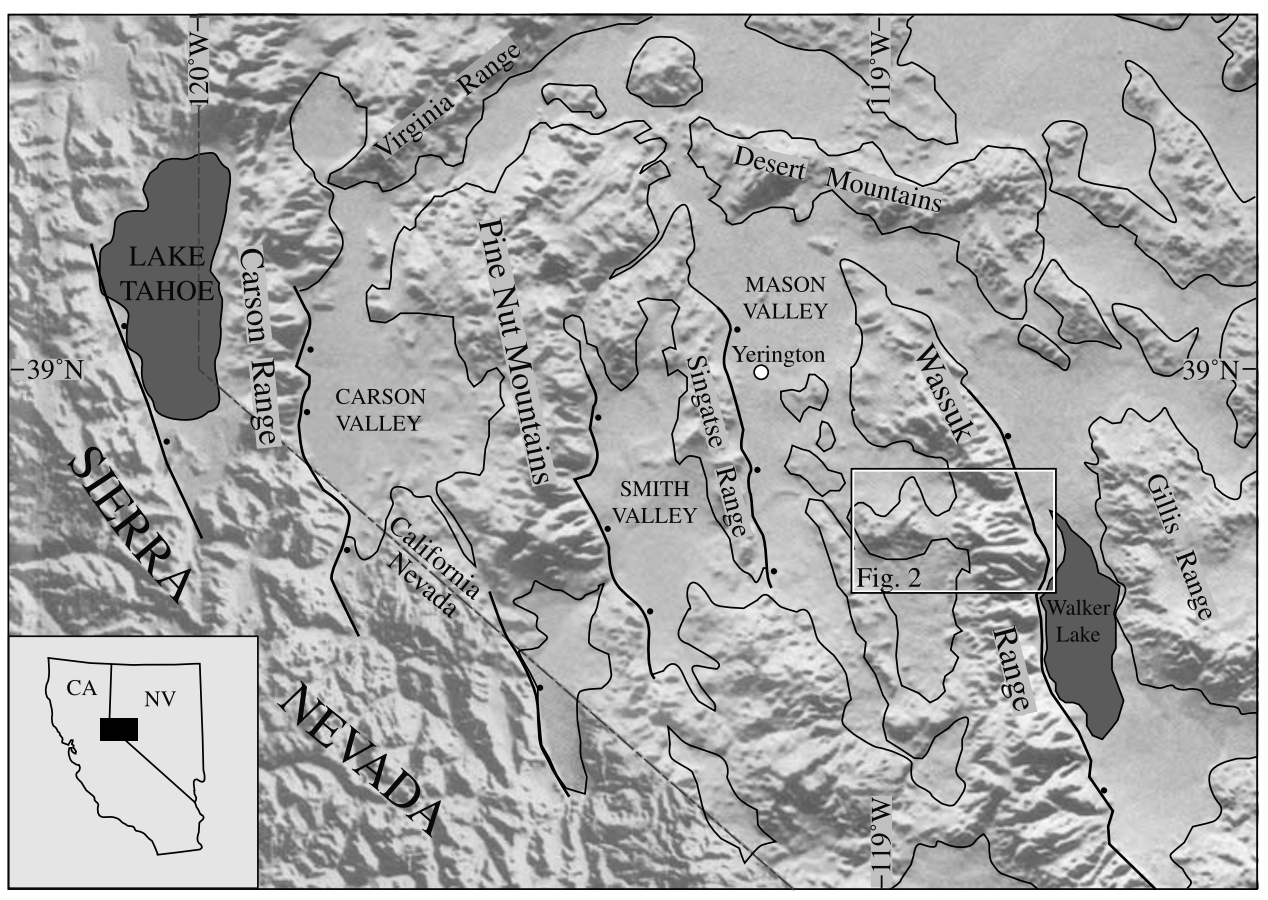

Figure 1. Digital shaded relief map of the western margin of the Basin and Range province with major mountain ranges labeled. Heavy solid lines indicate major present-day, east dipping, range-bounding normal faults. The white box outlines the map area of Figure 2. The Wassuk and Carson range-bounding faults are the most seismically active today and display components of both normal and dextral motion.

tion and to study the thermal structure of the upper crust immediately prior to and during extension. These thermochronological methods are particularly powerful when used together and when integrated over a wide range of preextensional paleodepths, as they provide time-temperature histories for individual samples over the temperature range $40^{\circ}-$ $110^{\circ} \mathrm{C}$. The integrated structural and thermochronological approach also provides important insights into the temporal relationship between extensional faulting and volcanism and into the issue of whether extensional faulting in the central Wassuk Range area was continuous or episodic in nature through time.

\section{Geological Setting}

[4] Tertiary extensional faulting along the western margin of the Basin and Range province at the latitude of Lake Tahoe is characterized by a series of tilted fault block bounded by east dipping normal faults [Moore and Archbold, 1969; Proffett, 1977; Stewart et al., 1984; Surpless, 1999] (Figure 1). The Wassuk Range trends approximately $\mathrm{N}-\mathrm{S}$ and is bound on its eastern flank by a major east dipping, high-angle normal fault. The central Wassuk Range consists of Jurassic and Cretaceous intrusive rock and Triassic and metavolcanic rocks thought to be correlative with metamorphic rocks exposed in the Singatse Range to the west [Bingler, 1978; Proffett and Dilles, 1984; Surpless, 1999]. The Mesozoic granitic rocks represent portions of the former Sierran magmatic arc, dissected by Basin and Range faulting and extension. An unconformity probably developed subsequent to crustal thickening during the late stages of Sierran magmatism as a result of Late Cretaceous-early Tertiary uplift and erosion [e.g., Wernicke, 1992] (Figures 2 and 3). This Late Cretaceous-early Tertiary unconformity is overlain by the Oligocene Mickey Pass and Singatse rhyolite ash flow tuffs in the Wassuk Range and Singatse Range. These thick Oligocene rhyolite tuffs are thought to be associated with a major southward sweep of intermediate to silicic volcanism in the northern Basin and Range prior to extension [Proffett and Proffett, 1976; Stewart, 1980; Christiansen et al., 1992; Glazner and Bartley, 1984]. The extrusion of the Lincoln Flat andesite at $\sim 15 \mathrm{Ma}$ also predates the onset of extensional faulting in the central Wassuk Range [Surpless, 1999]. During extensional faulting as evidenced by progressive tilting of volcanic units, only minor, localized basaltic andesite flows were erupted and sedimentation of the early Wassuk Group took place [Dilles, 1992; Surpless, 1999]. These Tertiary sedimentary and volcanic deposits and their stratal orientations bracket the timing of fault motion, the magnitude of fault block tilting, and the total displacements along individual normal faults.

\section{Structural Geology of The Central Wassuk Range Area}

[5] The structural analysis presented here is based on detailed geologic mapping and compilation by Surpless [1999], which includes previous geologic mapping by McIntyre [1990]. The stratigraphy and structural style of faulting 


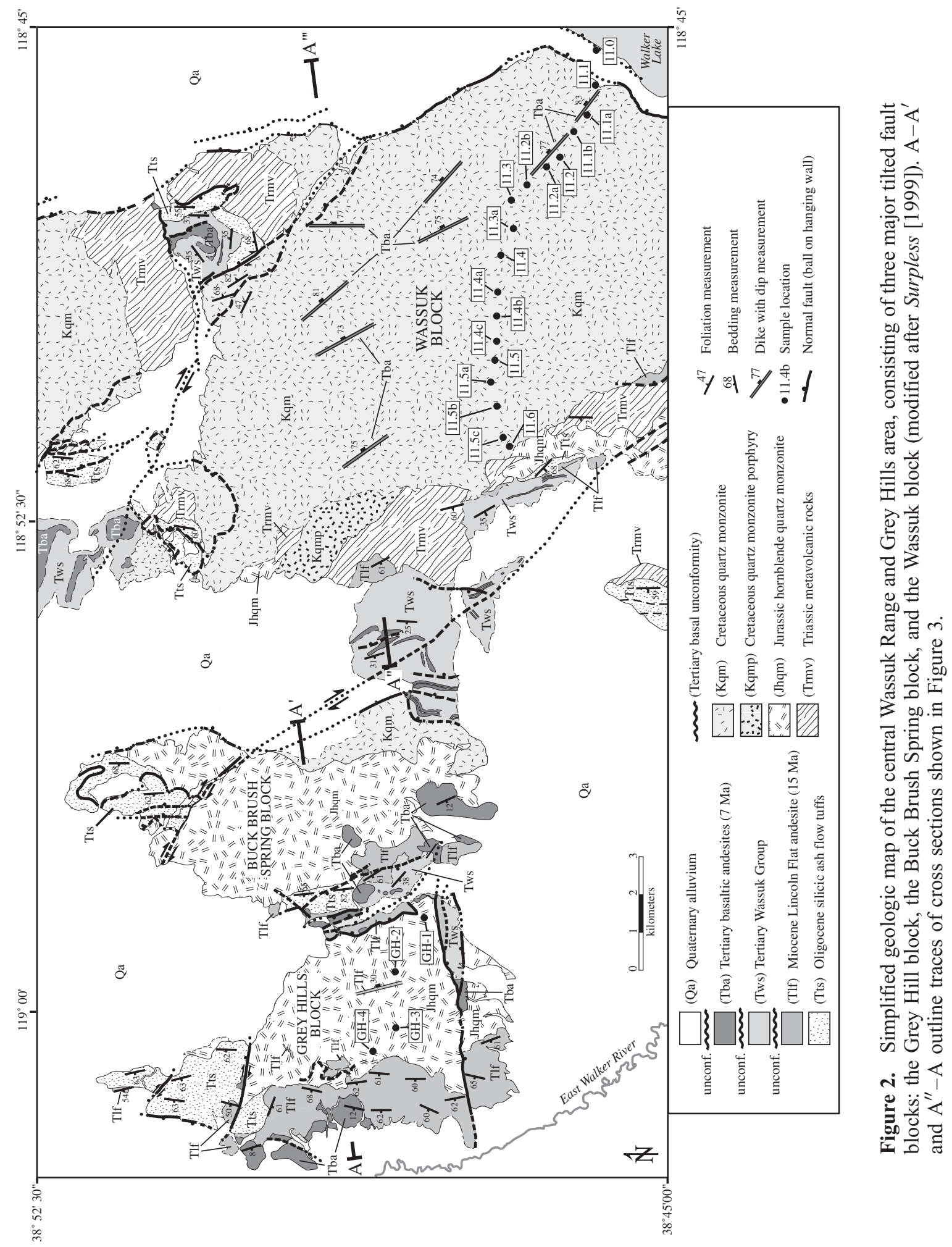



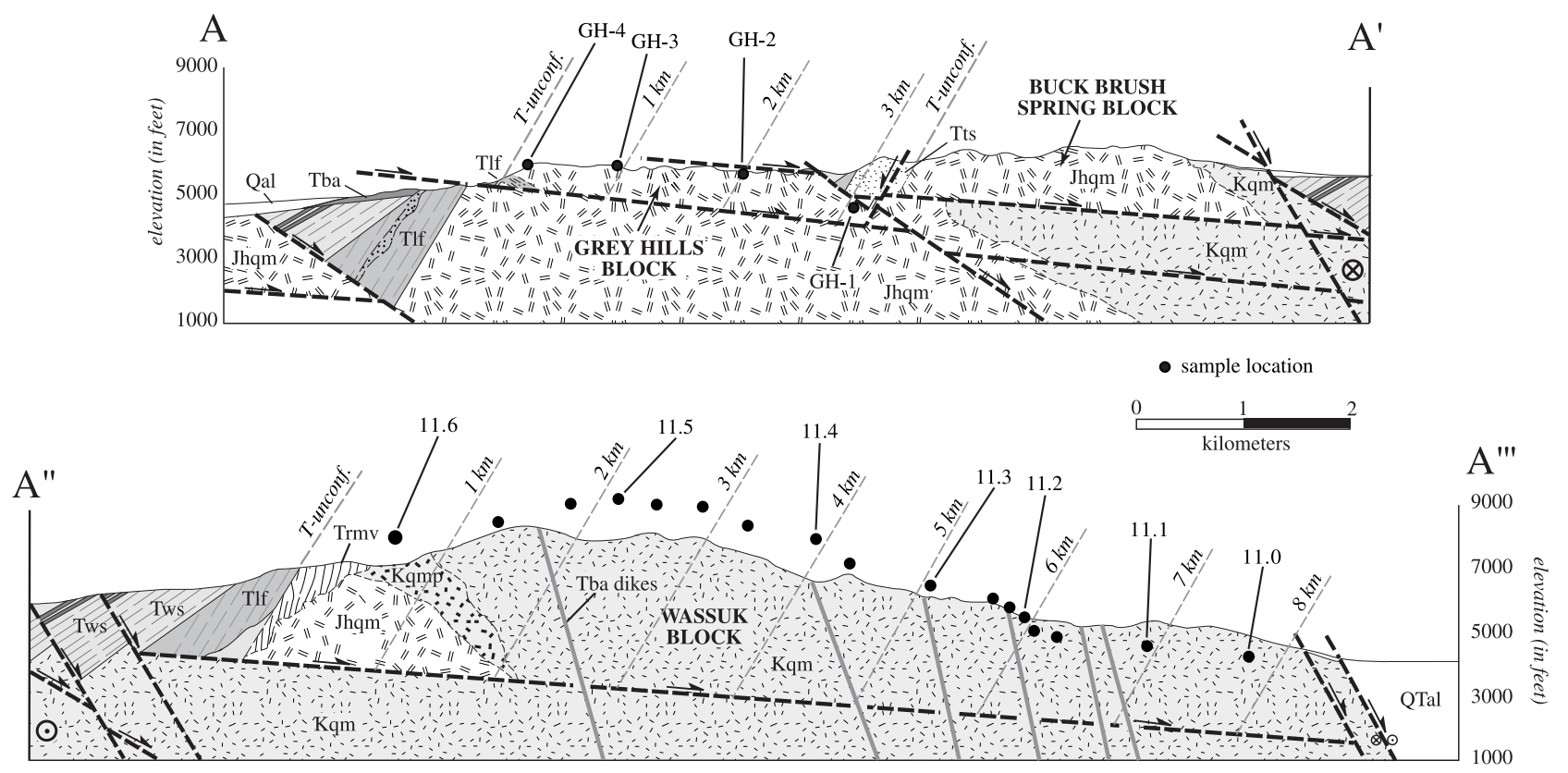

Figure 3. Simplified cross sections of the central Wassuk Range (modified after Surpless [1999]). Fault blocks are tilted to the west $\sim 60^{\circ}$ and expose a cross-sectional view of the upper crust. Thermochronological samples were collected from a range of paleodepths in the Grey Hills and Wassuk blocks. Samples were not collected from the Buck Brush Spring block because of extensive hydrothermal alteration of the Jurassic quartz monzonite.

in the central Wassuk Range map area are similar to that documented in the Singatse Range to the west [Proffett, 1977; Proffett and Dilles, 1984; Dilles and Gans, 1995] (Figure 1). In the study area, most normal faults strike north to NNW and have accommodated large-magnitude extension in a $\sim$ WSW-ENE direction. These normal faults caused westward tilting of fault blocks about a N-NNW striking horizontal axis, as defined by the westward tilting of Oligocene to Miocene volcanic rocks. The Tertiary stratigraphic section is structurally repeated multiple times across the map area, defining the Grey Hills, Buck Brush Spring, and Wassuk fault blocks from east to west (Figures 2 and 3). The seismically active fault zone along the modern range front strikes $\sim \mathrm{NNW}$ and accommodates oblique dextral faulting that appears to be associated with right-lateral shearing within the Walker Lane belt [Oldow, 1992; Stewart, 1992; Surpless, 1999]. Extensional deformation in the central Wassuk Range is characterized entirely by brittle faulting, with no evidence for mylonitization of any footwall rocks. Extensive cataclastic deformation is best exposed along the active range front fault system of the Wassuk Range.

\subsection{Faulting History of the Central Wassuk Range}

[6] Large-magnitude crustal extension in the central Wassuk Range area was accommodated along east dipping normal faults that initiated at high angles. These first generation faults have been progressively tilted westward during footwall exhumation and subsequently further rotated to very shallow to subhorizontal attitudes by younger generations of east dipping normal faults
[Surpless, 1999] (Figure 3). Although these early normal faults are generally poorly exposed in the map area, they clearly cut and tilt both the preextensional Oligocene Mickey Pass and Singatse silicic ash flow tuffs and the Miocene Lincoln Flat andesite flows. Where exposed, these faults are characterized by fault zone silicification and alteration of volcanic rocks adjacent to fault surfaces. The lack of significant westward tilting during the time span between deposition of Oligocene rhyolite tuffs and Miocene andesites (Figures 2, 3, and 4) implies that Tertiary extensional faulting postdates the extrusion of the Miocene Lincoln Flat andesite dated at $\sim 15.0-14.8$ Ma [Dilles and Gans, 1995; Surpless, 1999]. The Lincoln Flat andesite represents the youngest preextensional unit and defines a preextensional paleohorizontal reference datum (Figures 2 and 3).

[7] During extensional faulting no volcanism is documented in the central Wassuk Range with the exception of a small synextensional basaltic andesite flow exposed in the western Grey Hills. This flow, dated at $14.39 \pm 0.04 \mathrm{Ma}$, unconformably overlies the Lincoln Flat andesite and dips only $\sim 35^{\circ}$ to the west [Surpless, 1999], suggesting $\sim 25^{\circ}$ westward tilt during the first $\sim 0.4-0.6$ m.y. after the onset of extension in the central Wassuk Range. After extrusion of this synextensional flow, no more volcanic rocks were extruded until the deposition of basaltic andesite flows of the late Miocene Wassuk Group dated at $8.63 \pm 1.22 \mathrm{Ma}$ [McIntyre, 1990; Dilles, 1992; Surpless, 1999].

[8] A younger generation of east dipping normal faults appears to have controlled the sedimentation of early Wassuk Group strata in small, asymmetric half grabens 


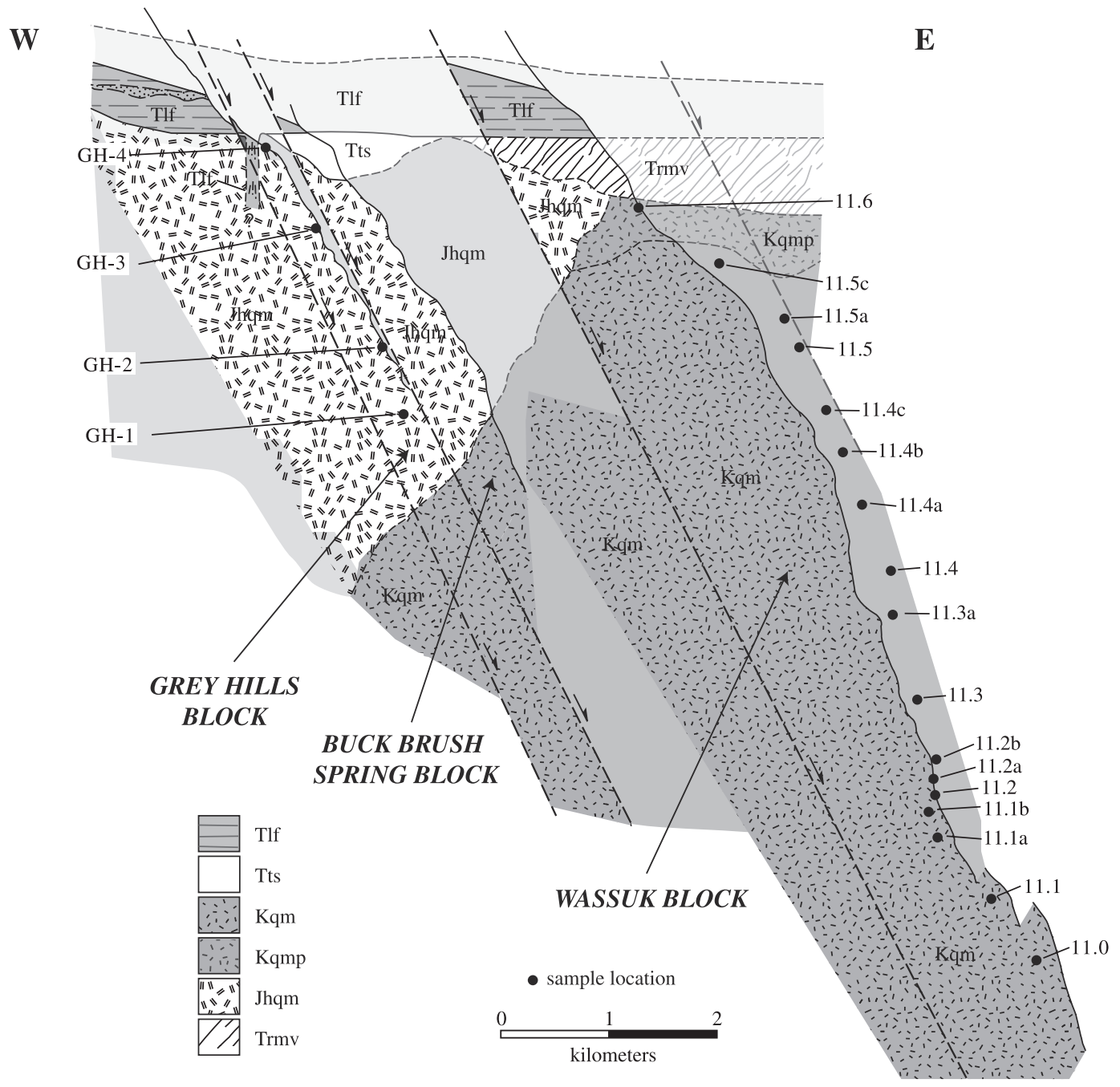

Figure 4. The structural reconstruction of the central Wassuk Range area prior to the onset of largemagnitude extensional faulting at $\sim 15 \mathrm{Ma}$ is based on the youngest preextensional stratigraphic marker unit, the Miocene Lincoln Flat andesite (Tlf). Lincoln Flat andesite flows indicate a total post-15 Ma west tilt of $\sim 60^{\circ}$. The total extension derived from this palinspastic restoration is $>200 \%$ [Surpless, 1999] The documented cumulative magnitude of westward fault block tilting from $15 \mathrm{Ma}$ to the present is consistent with paleomagnetic data from the Wassuk fault block, which indicate at least $60^{\circ}$ of westward tilting (J. Oldow and J. Geissman, personal communication, 1997). The preextensional paleodepth estimates derived from structural reconstruction of the pre-15 Ma geometry of the fault blocks permit the proper interpretation of the thermochronological data. Unit symbols given in Figure 2.

[McIntyre, 1990; Surpless, 1999]. Motion along these faults varied from dip-slip to dextral oblique slip and is well documented in the northern part of the central Wassuk Range, where dextral oblique motion has resulted in the formation of a rhomboidal pull-apart structure within the Wassuk Group sediments (Figure 2).

[9] Volumetrically minor basaltic andesite flows were erupted following deposition of the Wassuk Group [Surpless, 1999] (Figures 2 and 3). The oldest of these basaltic andesite flows, dated at $6.9 \mathrm{Ma}$, are now tilted up to $\sim 12^{\circ}$ to the west [McIntyre, 1990] (Figure 3). Similar basaltic andesite dikes within the Wassuk block dip steeply to the east $\left(78^{\circ} \pm 5^{\circ}\right.$ ), providing additional evidence for $\sim 12^{\circ}$ westward fault block rotations, assuming vertical dike emplacement (Figures 2 and 3). The episode of tilting beginning after $\sim 6.9$ $\mathrm{Ma}$ is ascribed to the active, high-angle normal fault system that bounds the east side of the Wassuk Range [Surpless, 1999]. Modern seismicity and fault scarp morphology 
suggest that this latest episode of faulting and footwall exhumation is an active and ongoing process.

\subsection{Wassuk and Grey Hills Fault Blocks}

[10] The Wassuk and Grey Hills fault blocks represent exhumed cross sections of preextensional upper crust, assuming the blocks are structurally intact and are tilted the same magnitude throughout. The base of the Miocene Lincoln Flat andesite is an assumed paleohorizontal frame of reference for paleodepth calculations in the Wassuk and Grey Hills fault blocks. Calculations of sample paleodepths were based on distance from the base of the Miocene Lincoln Flat andesite, a marker that now displays average dips of $60^{\circ} \pm 2^{\circ}$ to the west and temporally constrains the maximum age of the onset of extension and footwall tilting (Figures 3 and 4). The Buck Brush Spring fault block displayed ubiquitous sodic alteration and for this reason was avoided in thermochronologic sampling (Figure 2).

[11] The Wassuk fault block exposes a crustal section that consists mainly of Cretaceous Bald Mountain quartz monzonite with late-stage porphyritic intrusive rocks present near the roof of the pluton, which consists of Triassic metavolcanic rocks and Jurassic hornblende quartz monzonite (Figure 2). Swarms of aplitic dikes associated with the Bald Mountain pluton are present at shallow structural levels and were not sampled for thermochronology. In general, the Bald Mountain quartz monzonite is very homogenous and displays little variation in mineralogy and grain size with structural depth in the Wassuk fault block.

[12] The Grey Hills fault block exposes a $\sim 3 \mathrm{~km}$ structural section of Jurassic hornblende quartz monzonite, tentatively assigned to the Shamrock batholith exposed to the west (Figure 2). The Jurassic hornblende quartz monzonite includes localized exposures of quartz diorite, best exposed in the northern Wassuk Range and dated by $\mathrm{U}-\mathrm{Pb}$ at 232.7 $\pm 2.9 \mathrm{Ma}$ [Dilles and Gans, 1995]. Gently eastward dipping zones of sodic alteration within the Jurassic quartz monzonite at shallow structural levels of the Grey Hills fault block were avoided in sampling. Triassic metavolcanic rocks are absent from the Grey Hills fault block, but, as in the Wassuk fault block, homoclinally tilted Lincoln Flat andesite flows provide a paleohorizontal frame of reference. Andesitic dikes associated with the Lincoln Flat andesite dip $\sim 30^{\circ}$ eastward (Figure 3 ) and support $\sim 60^{\circ}$ of westward fault block rotation [Surpless, 1999].

\subsection{Preextensional Paleodepth Estimates}

[13] The Wassuk and Grey Hills fault blocks expose $\sim 8.5$ $\mathrm{km}$ and $\sim 3 \mathrm{~km}$, respectively, of structurally intact upper crustal section as measured downward from the westward dipping Miocene Lincoln Flat andesite. Several factors including the topography of the Tertiary unconformity, preextensional volcanic and sedimentary overburden, and potential errors in post-15 Ma tilt need to be considered in order to accurately estimate the preextensional depths of thermochronology samples in the Wassuk and Grey Hills fault blocks. The planar nature of the Tertiary unconformity provides evidence for only minor topographic relief prior to deposition of preextensional Tertiary volcanic units (Figures 2 and 4). Perturbations in thermal structure and warping of isotherms related to surface topography likely only affect samples at shallow structural levels and should be insignificant, given the relatively small magnitude and wavelength of the observed preextensional topography [Mancktelow and Grasemann, 1997]. With this in mind, paleodepth measurements are based on structural depth below a calculated paleohorizontal reference plane, which is taken to be the Tertiary unconformity. This planar frame of reference was calculated by averaging the differences in structural depth for individual samples caused by minor relief of the Tertiary unconformity, suppressing topographic effects from paleodepth measurements.

[14] The preextensional volcanic and sedimentary overburden above the Tertiary unconformity at the onset of faulting must also be estimated. One way to estimate the minimum preextensional Cenozoic overburden is on the basis of the maximum preserved stratigraphy thickness above the unconformity. Structural reconstruction of the central Wassuk Range and Grey Hills area suggests a minimum preextensional Cenozoic volcanic and sedimentary overburden of $\sim 500-800 \mathrm{~m}$ (Figure 4). The overburden thickness can also be estimated by apatite fission track modeling which constrains the thermal history of individual samples [Gallagher, 1995] (discussed in detail in section 6). Individual preextensional temperature estimates derived from fission track models plotted against sample paleodepths below the Tertiary unconformity suggest a preextensional overburden thickness of $\sim 0.8 \mathrm{~km}$, assuming an average annual surface temperature of $\sim 10^{\circ} \pm$ $5^{\circ} \mathrm{C}$ (Figure 5). This value is in good agreement with the reconstructed thickness of preextensional volcanic units above the Tertiary unconformity. Thus, for the proper estimation of preextensional paleodepths for individual thermochronological samples an overburden value of $\sim 0.8$ $\mathrm{km}$ was added to all sample paleodepths (Tables 1 and 2).

[15] Uncertainties in the paleodepth estimates are primarily a function of the uncertainty in total westward footwall tilting. Although structural data indicate $60^{\circ} \pm 2^{\circ}$ of westward tilting of footwall blocks, we have calculated the effects of $\mathrm{a} \pm 5^{\circ}$ uncertainty in tilting (Table 1).

\section{Apatite Fission Track and (U-Th)/He Thermochronology}

[16] Apatite fission track and (U-Th)/He dating methods are ideal for investigating the cooling and exhumation history of the Wassuk and Grey Hills fault blocks and the thermal structure of those blocks prior to faulting. When used together, these methods can provide time-temperature histories for individual samples over the temperature range $40^{\circ}-110^{\circ} \mathrm{C}$, which can be integrated with sample data from an entire range of exposed footwall paleodepths [e.g., Stockli et al., 2000].

[17] The apatite fission track dating method is well established and has been used extensively to constrain the low-temperature cooling histories of rocks in structurally intact exhumed footwall blocks of major normal faults [e.g., 


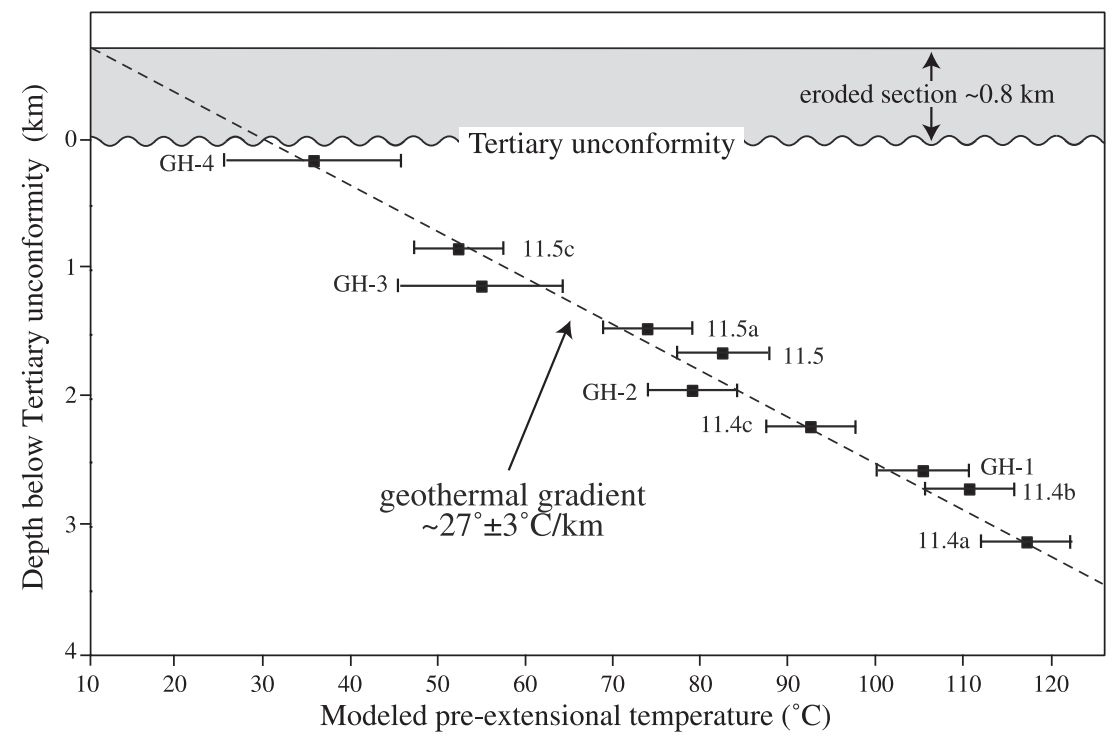

Figure 5. Thickness of eroded section approximated from the relationship between modeled preextensional temperature and depth below the Tertiary unconformity. The best fit line through samples which resided in and immediately below the apatite fission track PAZ prior to middle Miocene extension intercepts the assumed preextensional mean annual surface temperature $\left(10^{\circ} \pm 5^{\circ} \mathrm{C}\right)$ at $\sim 0.8 \mathrm{~km}$. Thermally defined paleosurface was at a position $\sim 0.8 \mathrm{~km}$ structurally above the plane defined by the Tertiary basal unconformity, which is consistent with the average regional thickness of volcanic and sedimentary overburden estimated for the onset of extension.

Fitzgerald et al., 1991; Foster et al., 1990, 1994; Gans et al., 1991; Howard and Foster, 1996; Miller et al., 1999; Stockli et al., 2000]. The use of fission track thermochronometry relies on the fact that tracks are partially or entirely erased at elevated temperatures, resulting in easily measured reductions in both track lengths and fission track ages [e.g., Naeser, 1979; Gleadow et al., 1986; Green et al., 1989a, 1989b; Corrigan, 1991; Crowley et al., 1991]. In apatite, all fission tracks are totally annealed (erased) above $\sim 110^{\circ} \mathrm{C}$ and partially annealed between $\sim 60^{\circ} \mathrm{C}$ and $\sim 110^{\circ} \mathrm{C}$, a temperature range termed the partial annealing zone (PAZ) [e.g., Gleadow et al., 1986; Green et al., 1989a]. Below $\sim 60^{\circ} \mathrm{C}$, fission tracks in apatite are effectively stable, annealing only at very slow rates [e.g., Fitzgerald and Gleadow, 1990]. If a sample rapidly cooled from temperatures greater than $\sim 110^{\circ} \mathrm{C}$ because of unroofing, then the measured age will directly record the age of extensional faulting and exhumation.

[18] The (U-Th)/He method is a relatively new thermochronological tool, but several studies have demonstrated the applicability of the technique [e.g., House et al., 1997, 1999; Wolf et al., 1997; Reiners et al., 2000; Stockli et al., 2000; Farley et al., 2001]. In apatite, He is entirely lost by diffusion above $\sim 80^{\circ} \mathrm{C}$ and partially retained between $\sim 40^{\circ}$ and $\sim 80^{\circ} \mathrm{C}$ [Wolf et al., 1998; Stockli et al., 2000]. The apatite (U-Th)/He partial retention zone (HePRZ) is conceptually analogous to the fission track PAZ and can be interpreted in a similar fashion. The low-temperature cooling histories attainable through the (U-Th)/He technique allow dating of neotectonic and small-magnitude tectonic motions in the upper crust, making apatite (U-Th)/He dating a powerful complement to the apatite fission track method.

\subsection{Apatite Fission Track Data and Results}

[19] A total of 22 thermochronology samples from the Grey Hills and the Wassuk fault blocks were collected along transects that encompass the entire exposed upper crustal section (Figure 3). All samples were taken from outcrops of fresh, unaltered intrusive rocks sufficiently distant from exposed dikes to avoid thermal effects. Only four samples were collected in the Grey Hills because of the limited structural depths exposed $(\sim 3 \mathrm{~km})$ and the extensive alteration of the Jurassic hornblende quartz monzonite. Systematic sampling was focused on the structurally intact Wassuk footwall block which exposes $\sim 8.5 \mathrm{~km}$ of preextensional upper crust (Figures 3 and 4), although at paleodepths $<3 \mathrm{~km}$ apatite yields were low and of generally poor quality. Apatite fission track and (U-Th)/He analyses for individual samples were performed on the same apatite separates, eliminating compositional or local thermal effects. The data from the Grey Hills and the Wassuk fault blocks are interpreted together because of their spatial proximity prior to the onset of Miocene extension (Figure 4).

[20] Apatite fission track data from the Wassuk and Grey Hills fault blocks exhibit systematic apparent age versus paleodepth and track length versus paleodepth patterns indicative of rapid footwall exhumation [e.g., Fitzgerald et al., 1991; Howard and Foster, 1996; Miller et al., 1999; Stockli et al., 2000]. Apparent ages decrease with increasing paleodepths from $68.5 \pm 5.3 \mathrm{Ma}$ immediately below the 


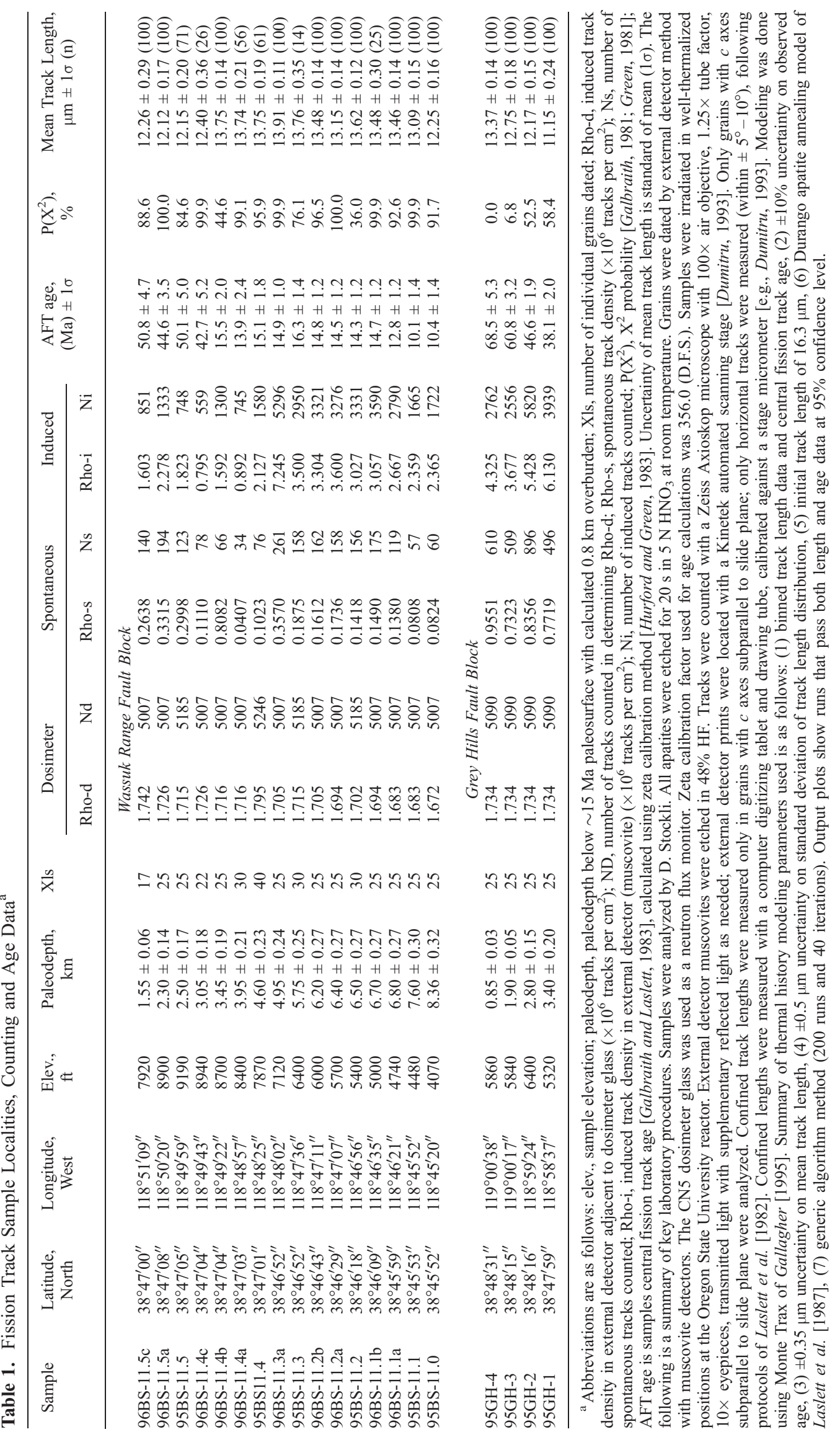


Table 2. Apatite (U-Th)/He Results for Wassuk and Grey Hills Fault Blocks ${ }^{\mathrm{a}}$

\begin{tabular}{|c|c|c|c|c|c|c|c|c|c|}
\hline Sample & $\begin{array}{l}\text { Latitude, } \\
\text { North }\end{array}$ & $\begin{array}{l}\text { Longitude, } \\
\text { West }\end{array}$ & Elev., ft & $\begin{array}{l}\text { Paleodepth, } \\
\text { km }\end{array}$ & $\begin{array}{c}\mathrm{He}, \\
\mathrm{nmol} / \mathrm{g}\end{array}$ & $\mathrm{U}, \mathrm{ppm}$ & Th, ppm & $\begin{array}{l}\text { Correction } \\
\text { factor, Ft }\end{array}$ & $\begin{array}{l}\text { Corrected age } \\
\text { (Ma) } \pm 1 \sigma\end{array}$ \\
\hline \multicolumn{10}{|c|}{ Wassuk Range Fault Block } \\
\hline 95BS-11.6 & $38^{\circ} 46^{\prime} 52^{\prime \prime}$ & $118^{\circ} 46^{\prime} 20^{\prime \prime}$ & 7900 & $1.50 \pm 0.04$ & 3.94 & 15.3 & 29.8 & 0.62 & $52.8 \pm 1.9$ \\
\hline 95BS-11.5 & $38^{\circ} 47^{\prime} 05^{\prime \prime}$ & $118^{\circ} 49^{\prime} 59^{\prime \prime}$ & 9190 & $2.50 \pm 0.17$ & 1.37 & 8.9 & 17.1 & 0.63 & $31.2 \pm 2.3$ \\
\hline 95BS-11.4 & $38^{\circ} 47^{\prime} 01^{\prime \prime}$ & $118^{\circ} 48^{\prime} 25^{\prime \prime}$ & 7870 & $4.60 \pm 0.23$ & 0.93 & 15.6 & 12.6 & 0.64 & $14.5 \pm 1.6$ \\
\hline 95BS-11.3 & $38^{\circ} 46^{\prime} 52^{\prime \prime}$ & $118^{\circ} 47^{\prime} 36^{\prime \prime}$ & 6400 & $5.75 \pm 0.25$ & 0.66 & 12.7 & 23.0 & 0.69 & $9.9 \pm 0.9$ \\
\hline 95BS-11.2 & $38^{\circ} 46^{\prime} 18^{\prime \prime}$ & $118^{\circ} 46^{\prime} 56^{\prime \prime}$ & 5400 & $6.50 \pm 0.27$ & 0.60 & 18.8 & 25.9 & 0.64 & $7.0 \pm 1.0$ \\
\hline $96 \mathrm{BS}-11.1 \mathrm{a}$ & $38^{\circ} 45^{\prime} 59^{\prime \prime}$ & $118^{\circ} 46^{\prime} 21^{\prime \prime}$ & 4740 & $6.80 \pm 0.27$ & 0.42 & 12.4 & 19.1 & 0.69 & $6.7 \pm 0.6$ \\
\hline 95BS-11.1 & $38^{\circ} 45^{\prime} 53^{\prime \prime}$ & $118^{\circ} 45^{\prime} 52^{\prime \prime}$ & 4480 & $7.60 \pm 0.30$ & 0.24 & 13.7 & 20.2 & 0.63 & $3.9 \pm 0.8$ \\
\hline \multicolumn{10}{|c|}{ Grey Hills Fault Block } \\
\hline $95 \mathrm{GH}-4$ & $38^{\circ} 48^{\prime} 31^{\prime \prime}$ & $119^{\circ} 00^{\prime} 38^{\prime \prime}$ & 5860 & $0.85 \pm 0.03$ & 5.33 & 19.0 & 40.9 & 0.74 & $46.5 \pm 2.3$ \\
\hline $95 \mathrm{GH}-3$ & $38^{\circ} 48^{\prime} 15^{\prime \prime}$ & $119^{\circ} 00^{\prime} 17^{\prime \prime}$ & 5840 & $1.90 \pm 0.05$ & 3.62 & 19.4 & 39.2 & 0.76 & $36.5 \pm 1.5$ \\
\hline $95 \mathrm{GH}-2$ & $38^{\circ} 48^{\prime} 16^{\prime \prime}$ & $118^{\circ} 59^{\prime} 24^{\prime \prime}$ & 6400 & $2.80 \pm 0.15$ & 2.80 & 33.5 & 58.8 & 0.73 & $15.1 \pm 0.7$ \\
\hline $95 \mathrm{GH}-1$ & $38^{\circ} 47^{\prime} 59^{\prime \prime}$ & $118^{\circ} 58^{\prime} 37^{\prime \prime}$ & 5320 & $3.40 \pm 0.20$ & 2.38 & 25.4 & 40.1 & 0.79 & $16.0 \pm 0.8$ \\
\hline
\end{tabular}

${ }^{a}$ Abbreviations are as follows: elev., elevation; paleodepth, middle Miocene paleodepth (see text). Errors on corrected age reflect two standard deviations. The dimensions of the apatite grains in each sample (5-15 grains) were measured to determine an alpha-emission correction (Ft correction factor of Farley et al. [1996]). (U-Th)/He ages were calculated based on absolute He and U-Th determinations on the same sample. For helium analyses, samples were first outgassed, then retrieved and dissolved in a doubly spiked $\left({ }^{230} \mathrm{Th}^{235} \mathrm{U}\right) \mathrm{HNO}_{3}$ solution in preparation for $\mathrm{U}$ and Th determinations using isotope dilution ICP-MS. Analyses were performed at the California Institute of Technology (see Stockli et al. [2000] for analytical procedures). Errors are analytical errors only.

unconformity to $15.5 \pm 2.0 \mathrm{Ma}$ at $\sim 3.6 \mathrm{~km}$ paleodepth (Table 1; Figures 6, 7, and 8). Samples from high structural levels display relatively short mean track lengths characterized by unimodal, negatively skewed track length distributions that are indicative of protracted, monotonic cooling in the Late Cretaceous and early Tertiary.

[21] At a paleodepth of $3.6 \pm 0.2 \mathrm{~km}$ in the Grey Hills and Wassuk fault blocks, a major inflection occurs in both the fission track age and length versus paleodepth curves (Figures 8 and 9), defining the base of an exhumed Miocene PAZ. Mean lengths change from $\sim 12.40 \mu \mathrm{m}$ immediately above the base of the PAZ to $\sim 13.75 \mu \mathrm{m}$ below the PAZ. Sample GH-1 displays a distinctly shorter mean track length of $11.15 \pm 0.24 \mu \mathrm{m}$, indicative of a greater degree of annealing. This might be explained by shear heating or flow of hydrothermal fluids along the nearby normal fault that bounds the eastern margin of the Grey Hills (Figures 7 and 9).

[22] Apparent fission track ages below $3.6 \pm 0.2 \mathrm{~km}$ paleodepth are virtually constant at $\sim 15 \mathrm{Ma}$ (Figures 8 and 10). These samples display unimodal, narrow track length distributions and relatively long mean track lengths ranging from $\sim 13.8 \mu \mathrm{m}$ to $\sim 13.6 \mu \mathrm{m}$ (Figure 9). Concordant track lengths $(\sim 13.7 \mu \mathrm{m})$ and cooling ages $(\sim 15 \mathrm{Ma})$ over a paleodepth interval of $\sim 3 \mathrm{~km}$ are indicative of very rapid cooling and footwall exhumation starting at $\sim 15 \mathrm{Ma}$ and subsequent residence at slightly elevated temperatures $(T<$ $60^{\circ} \mathrm{C}$ ) in the uppermost crust, before final exhumation of these footwall rocks to near surface levels. The cooling event dated by these apparent ages is likely related to exhumation of footwall rocks by slip along normal faults which bound the Grey Hills and Wassuk fault blocks (Figures 2 and 3).

[23] At preextensional Miocene paleodepth levels $>6.6 \pm$ $0.2 \mathrm{~km}$ along the eastern flank of the central Wassuk Range, a gentle inflection occurs in both the fission track age versus paleodepth curve (Figure 8) and the track length versus paleodepth curve (Figure 9), with apparent ages slightly decreasing with increasing paleodepth. These samples are characterized by broad unimodal to slightly bimodal track length distributions and younger apparent ages (Figures 6, 7, and 9). These younger data likely suggest a multistage cooling history in the central Wassuk Range and the existence of a second exhumed Pliocene PAZ, related to high-angle normal faults along the Wassuk range front (Figures 2 and 3). As a consequence, partially reset age and length data from along the eastern range front are not plotted against Miocene paleodepth but against Pliocene paleodepth in order to avoid vertical distortion, to obtain more accurate constraints on the timing of faulting and to estimate the Pliocene geothermal gradient (Figure 11). Pliocene paleodepths were estimated by correcting present-day sample positions for a Pliocene footwall rotation of $\sim 12^{\circ}$ as deduced from westward tilted $\sim 7$ Ma basaltic andesite flows. This post-Miocene episode of cooling and uplift appears to be related the onset of active normal-dextral oblique faulting along the eastern side of the Wassuk Range and hanging wall subsidence of the Walker Lake basin.

\section{2. (U-Th)/He Data and Results}

[24] Apatite (U-Th)/He age data were collected from 11 samples in the central Wassuk Range and Grey Hills (Figures 6 and 7). The (U-Th)/He data from the central Wassuk Range and Grey Hills (Table 2) are in good agreement with the apatite fission track data and corroborate the Miocene cooling history of the fault blocks. In addition, the (U-Th)/He data further elucidate the younger faulting history along the eastern flank of the Wassuk Range. Because of the lower temperature interval recorded by the (U-Th)/He system [e.g., Wolf et al., 1998; Stockli et al., 2000], the 


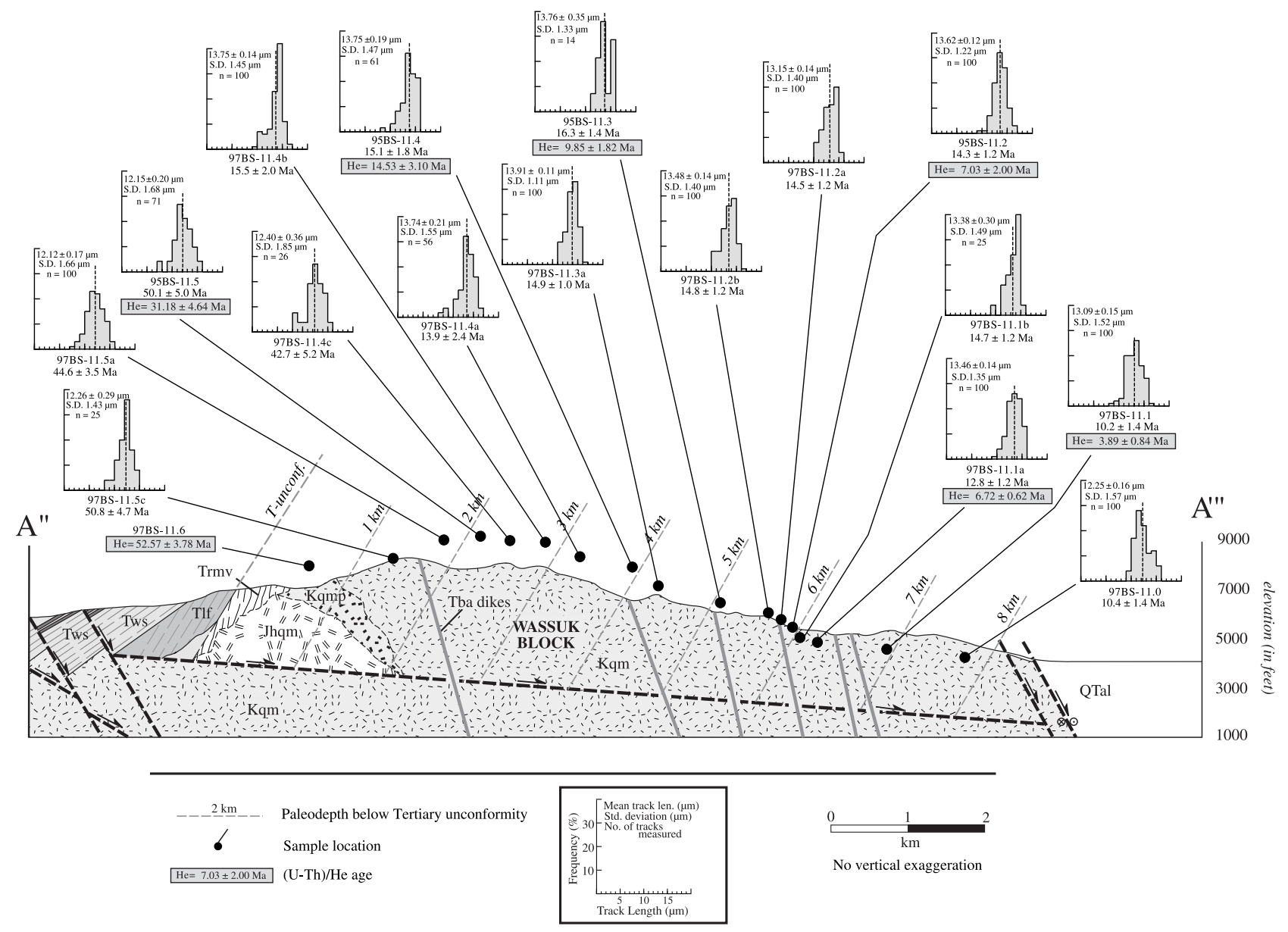

Figure 6. Simplified cross section of the Wassuk fault block with apatite fission track length histograms and apparent ages, and (U-Th)/He apparent ages (shaded boxes). Fault block is tilted to the west $\sim 60^{\circ}$ and exposes a cross-sectional view of the upper crust. See Tables 1 and 2 for apatite fission track and (U-Th)/He data, respectively. For legend see Figure 2.

technique generally yields younger apparent ages than the fission track method for individual samples. Apparent (U-Th)/He ages decrease to the east with increasing paleodepth, from 52.8 $\pm 1.9 \mathrm{Ma}$ to $3.9 \pm 0.8 \mathrm{Ma}$ (Figures 6, 7, and 8). Data from structurally shallow samples define the upper portion of the (U-Th)/He apparent age versus paleodepth curve and show a systematic correlation of paleodepth and apparent (U-Th)/He age, characteristic of samples which resided in the HePRZ prior to rapid middle Miocene exhumation.

[25] At paleodepths of $2.9 \pm 0.2 \mathrm{~km}$ in the Wassuk Range, an inflection occurs in the (U-Th)/He age versus Miocene paleodepth curve at an age of $\sim 15 \mathrm{Ma}$ (Figure 8 ). Immediately below the inflection point, (U-Th)/He ages are concordant with apatite fission track ages, indicating very rapid cooling and footwall exhumation in the middle Miocene starting at $\sim 15 \mathrm{Ma}$. Like the fission track ages, the invariant (U-Th)/He ages obtained from these samples are most likely related to rapid footwall exhumation due to slip along the now eroded normal fault which once bounded the upper surface of the Wassuk fault block (Figure 3).
[26] At Miocene paleodepths of $\sim 4.7 \mathrm{~km}$ in the Wassuk fault block, a gentle inflection occurs in the (U-Th)/He age versus paleodepth curve (Figure 8), indicating a renewed uplift event in Pliocene time. As in the case of the exhumed Pliocene apatite fission track PAZ, these younger (U-Th)/He samples are replotted against Pliocene paleodepth to avoid vertical distortion (Figure 11). The structurally lowest (U$\mathrm{Th}) / \mathrm{He}$ sample yields an age of $3.9 \pm 0.8 \mathrm{Ma}$. Reconstruction of complete age versus paleodepth curves suggests that this is a probable cooling age (see section 5), indicating that the sample resided immediately below the base of the HePRZ at temperatures $>80^{\circ} \mathrm{C}$ prior to Pliocene faulting. The timing of renewed faulting suggested by (U-Th)/He data appears to be in good agreement with fission track modeling results (see section 6) and indicates renewed faultrelated cooling after $\sim 4 \mathrm{Ma}$.

\section{Interpretation of Thermochronological Data}

[27] Apatite fission track and (U-Th)/He data record rapid cooling and exhumation of the upper crust as a 


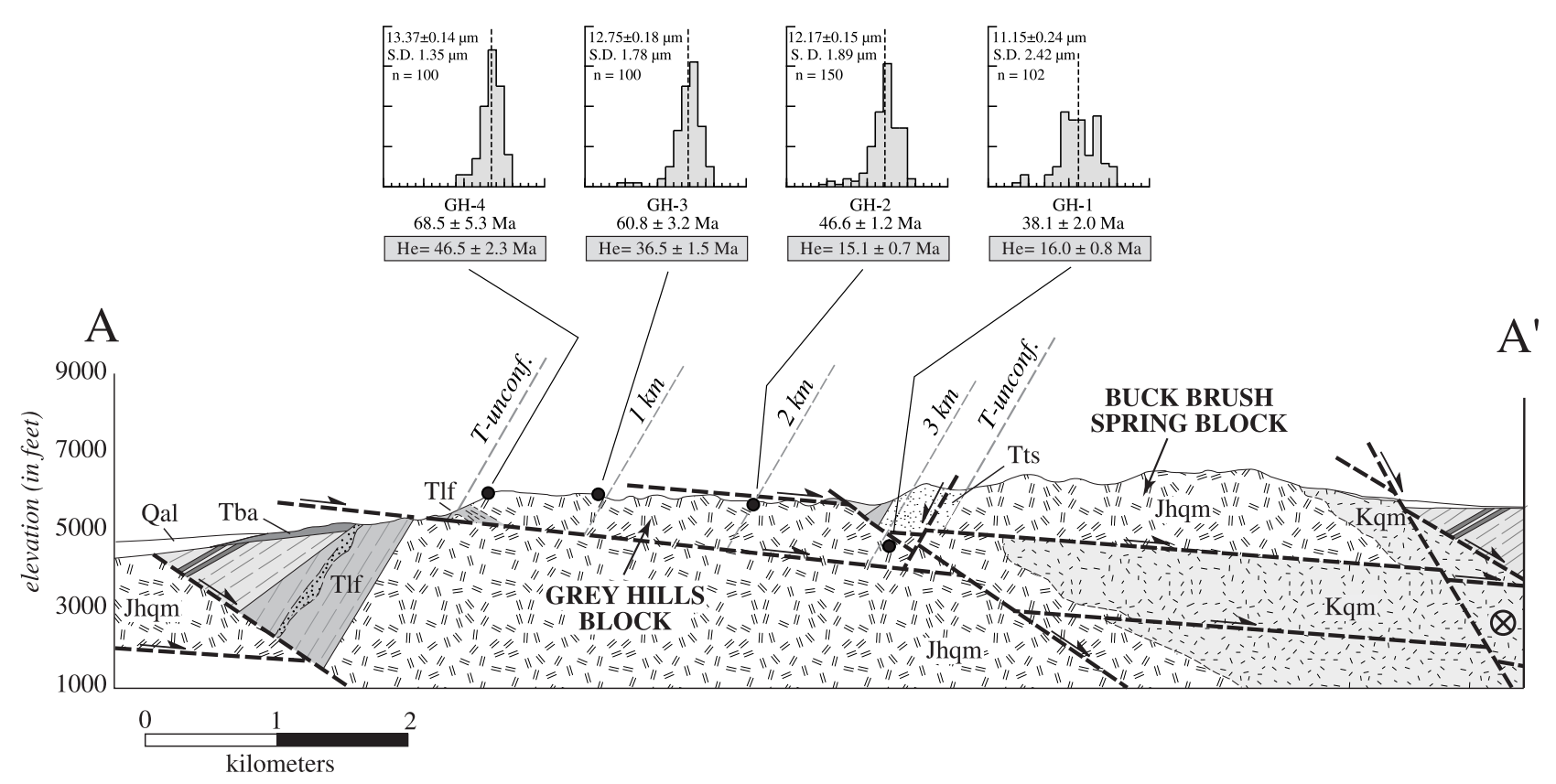

Figure 7. Simplified cross section of the Grey Hills fault block with apatite fission track length histograms and apparent ages, and (U-Th)/He apparent ages (shaded boxes). See Figures 2 and 6 for legend.

consequence of large magnitude extension and indicate that tilting of the Grey Hills and Wassuk fault blocks began at $\sim 15 \mathrm{Ma}$. The timing of onset of extension and fault block tilting agrees well with the tilt history bracketed by Tertiary volcanic and sedimentary deposits. The apatite fission track and (U-Th)/He age versus paleodepth curves (Figure 8), with inflection points at $\sim 3.6 \mathrm{~km}$ and $\sim 2.9 \mathrm{~km}$, respectively, resemble profiles from other tilted, intact fault blocks [e.g., Reiners et al., 2000; Stockli et al., 2000] and borehole studies [e.g., Green et al., 1989a; House et al., 1999] in which the structurally shallow part of the curve records progressive age reduction in a zone of partial annealing/ retention. Structurally deeper samples record rapid cooling and exhumation of rocks that were previously residing below the PAZ or HePRZ [e.g., Bryant and Naeser, 1980; Fitzgerald et al., 1991; Gleadow and Fitzgerald, 1987; Howard and Foster, 1996; Stockli et al., 2000]. The structurally deepest samples record renewed Pliocene exhumation or less likely protracted post-Miocene cooling. The inflections in both apatite fission track and (U-Th)/He apparent age versus paleodepth curves are interpreted to represent the base of the fission track PAZ for apatite $\left(\sim 110^{\circ} \mathrm{C}\right)$ and the base of the apatite HePRZ $\left(\sim 80^{\circ} \mathrm{C}\right)$ prior to major fault slip and resultant footwall exhumation and cooling.

[28] Apatite fission track and (U-Th)/He data provide several methods for estimating the geothermal gradient immediately prior to the onset of middle Miocene extension in the central Wassuk Range fault blocks. While it is unlikely that geothermal gradients were linear with depth during extension, linearity can probably be assumed at shallow crustal levels. One method is to determine the temperature difference between the Tertiary paleosurface and the depth to the observed inflection in the apatite fission track age versus depth or fission track length-depth curves $\left(\sim 110^{\circ} \mathrm{C}\right)$ (Figures 6 and 8 ). Assuming a mean annual surface temperature of $10^{\circ} \pm 5^{\circ} \mathrm{C}$ and the paleodepth of the inflection point $(3.6 \pm 0.2 \mathrm{~km})$ yields a geothermal gradient estimate of $27^{\circ} \pm 5^{\circ} \mathrm{C} / \mathrm{km}$ at the onset of Tertiary extension. The distance from the Tertiary unconformity to the base of the HePRZ can similarly be used to estimate the preextensional Miocene geothermal gradient. A paleodepth of $2.9 \pm 0.2 \mathrm{~km}$ for the (U-Th)/he inflection point suggests a preextensional geothermal gradient of $26^{\circ} \pm 5^{\circ} \mathrm{C} / \mathrm{km}$. In addition, the difference in paleodepths between the base of the PAZ and the HePRZ can be used to estimate a geothermal gradient, although associated uncertainties are large because of the relatively small difference in paleodepths and temperatures. This method yields a rough estimate of $31^{\circ} \pm$ $10^{\circ} \mathrm{C} / \mathrm{km}$ for the preextensional Miocene geothermal gradient. The preextensional geothermal gradient value obtained from the (U-Th)/He data $\left(26^{\circ} \pm 5^{\circ} \mathrm{C} / \mathrm{km}\right)$ is consistent with the estimate derived from the fission track data $\left(27^{\circ} \pm 5^{\circ} \mathrm{C} / \mathrm{km}\right)$ and is similar to preextensional geothermal gradient estimates for the Basin and Range province [e.g., Fitzgerald et al., 1991; Foster et al., 1994; Stockli, 1999].

[29] Potential transient thermal effects related to the volcanic overburden $(\sim 0.8 \mathrm{~km})$ deposited immediately prior to the onset of rapid middle Miocene extension are negligible. Simple calculations which take into account thermal diffusivities of upper crustal lithologies indicate that a geotherm perturbation caused by a small $(\sim 1 \mathrm{~km})$ addition to the rock column should decay within $\sim 10,000$ to 100,000 years and that isotherms should rapidly reequilibrate. However, the uncertainty related to the time- 


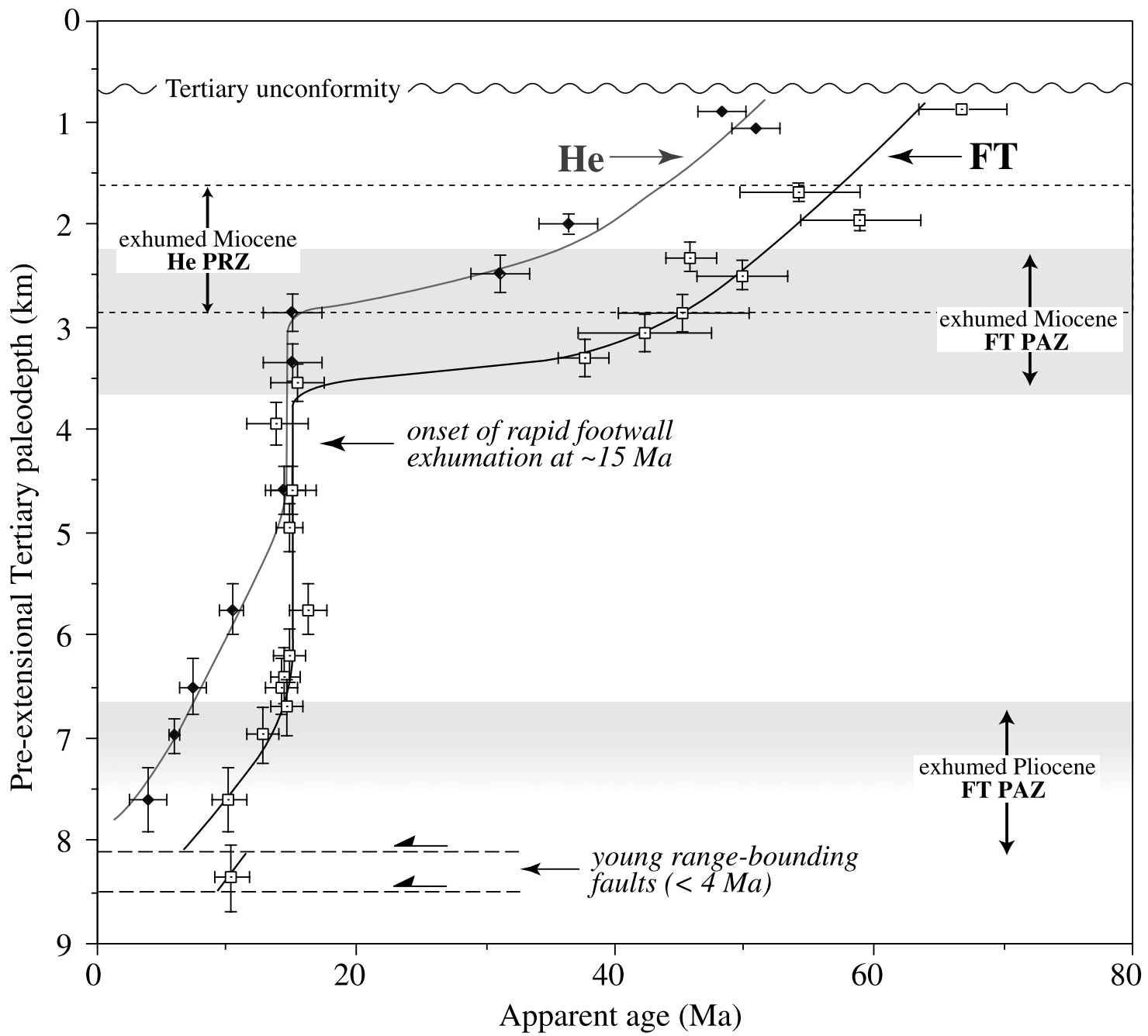

Figure 8. Fission track (FT) and (U-Th)/He thermochronological data from the central Wassuk Range and Grey Hills plotted against preextensional Miocene paleodepth illustrating the Miocene exhumation history. The data show clear inflection points at $\sim 15$ Ma marking the onset of very rapid cooling and exhumation at that time. Cooling ages below the inflection points are invariant over a wide range of structural relief indicating very rapid cooling rates. PAZ and PRZ defined as by Stockli et al. [2000].

dependent behavior of apatite fission track annealing in response to such a short-term change in the temperature field as a function of depth is more difficult to assess and probably limits the accuracy of paleogeothermal gradient estimates to about $\pm 5^{\circ} \mathrm{C} / \mathrm{km}$.

[30] With the exception of the structurally deepest sample which yields a apparent (U-Th)/He cooling age of $3.9 \pm 0.8$ $\mathrm{Ma}$, apatite fission track and $(\mathrm{U}-\mathrm{Th}) / \mathrm{He}$ data from the eastern flank exhibit partially reset ages related to renewed Pliocene faulting and exhumation. The distance between the poorly defined tops of the Pliocene PAZ $\left(\sim 60^{\circ} \mathrm{C}\right)$ and HePRZ $\left(\sim 40^{\circ} \mathrm{C}\right)$ allows a crude estimation of a Pliocene paleogeothermal gradient of $32^{\circ} \pm 10^{\circ} \mathrm{C} / \mathrm{km}$ (Figure 11). This value is similar to estimates of modern geothermal gradients of $\sim 35^{\circ} \mathrm{C} / \mathrm{km}$ in the central portion of the western Basin and Range province [e.g., Lachenbruch and Sass, 1980]. This estimated Pliocene paleogeothermal gradient allows an approximation of paleodepths for the base of the PAZ and HePRZ and the position of the now eroded Pliocene paleosurface (Figure 11). The $3.9 \pm 0.8 \mathrm{Ma}$ (U-Th)/He age from a sample below the reconstructed Pliocene HePRZ and PAZ suggests renewed or accelerated Pliocene exhumation along range front faults starting at $\sim 4$ Ma. This structurally lowest (U-Th)/He sample along the active eastern range front of the central Wassuk Range resided immediately below the base of the PRZ at temperatures of $\sim 80^{\circ} \mathrm{C}$ prior to Pliocene faulting. The Pliocene geothermal gradient $\left(32^{\circ} \pm 8^{\circ} \mathrm{C} / \mathrm{km}\right)$ and a mean annual surface temperature of $\sim 10^{\circ} \pm 5^{\circ} \mathrm{C}$ therefore predict $2.5 \pm$ $0.5 \mathrm{~km}$ of exhumation along the range-bounding fault system on the eastern side of the central Wassuk Range, which is in agreement with previous estimates [McIntyre, 1990; Dilles, 1992]. However, additional structural and thermochronological data are needed to resolve temporal 


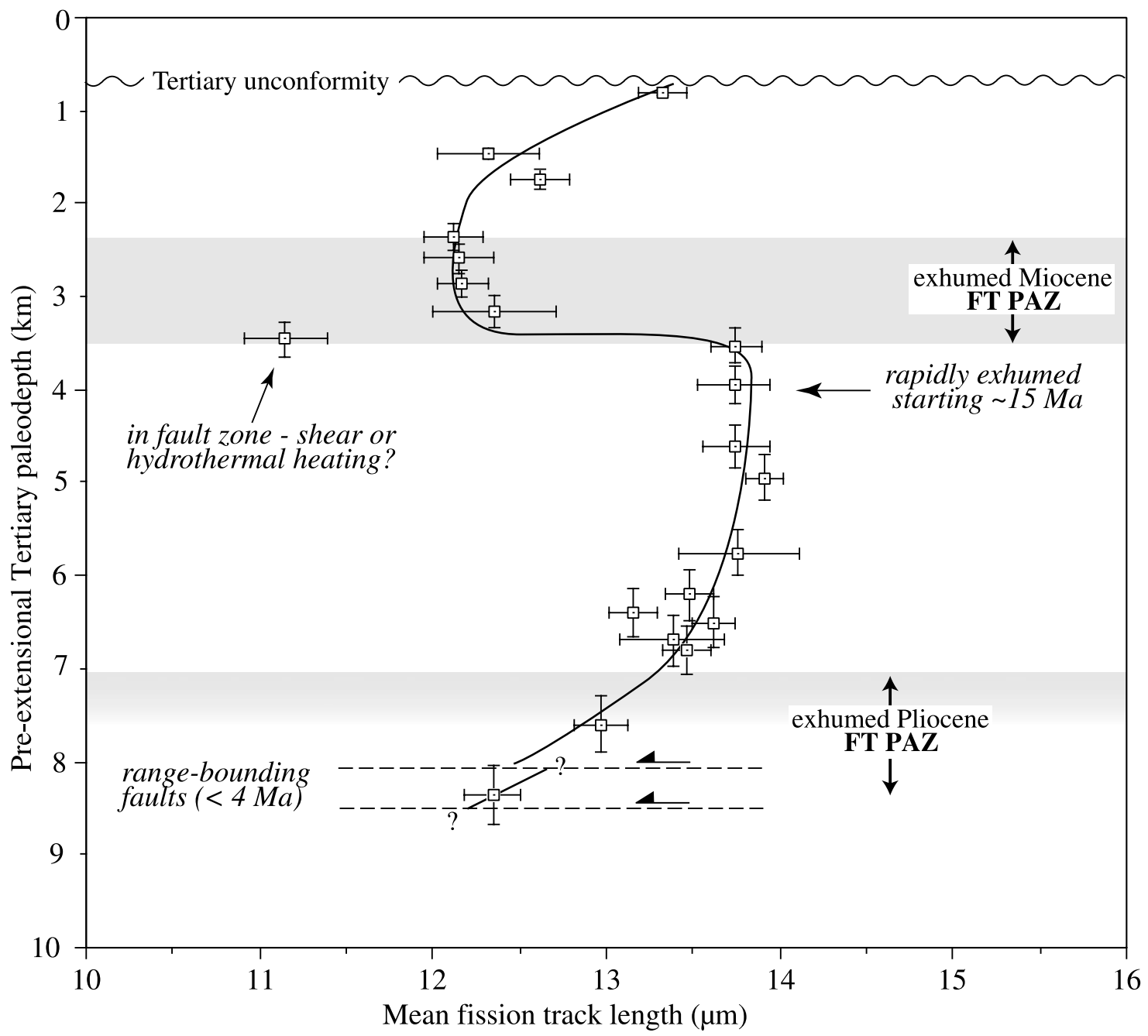

Figure 9. Mean apatite fission track length data plotted against preextensional Miocene paleodepth from the central Wassuk Range and the Grey Hills area. These data suggest the existence of two exhumed partial annealing zones in the central Wassuk Range. The mean track lengths of rapidly exhumed samples at $15 \mathrm{Ma}$ are all $<14 \mu \mathrm{m}$, suggesting residence above the PAZ at slightly elevated temperatures $\left(<60^{\circ} \mathrm{C}\right)$ after Miocene exhumation and before final exhumation in the Pliocene/Quaternary. Structurally lowest samples show a systematic reduction in length indicating that they resided at temperatures $>60^{\circ} \mathrm{C}$ after Miocene extension.

and thermal aspects of this recent episode of normal-dextral oblique faulting.

\section{Apatite Fission Track Length Modeling Results}

[31] Apatite fission track length distributions and age data were modeled using the Monte Trax program of Gallagher [1995]. The stochastic modeling program utilizes a Monte Carlo-type approach with a genetic algorithm. Partially annealed apatite fission track apparent age and length data were used to constrain the thermal evolution $\left(<110^{\circ} \mathrm{C}\right)$ of individual samples from exhumed fault blocks of the central Wassuk Range area. These model runs not only constrain the pre-Miocene cooling history of individual samples, but also allow the estimation of the preextensional volcanic and sedimentary overburden when interpreted together in the context of a paleodepth transect. Furthermore, the temporal aspects of younger exhumation along the present-day range bounding fault system are also revealed by these modeling results.

[32] Samples at structurally shallow were modeled to constrain the earlier, pre-Tertiary thermal evolution of the upper crust. Model results suggest a thermal history characterized by protracted cooling from Late Cretaceous through middle Tertiary time at rates of about $1{ }^{\circ} \mathrm{C} / \mathrm{Ma}$ (Figure 12). This is consistent with slow erosional unroofing of the central Wassuk Range region, followed by extrusion of voluminous silicic ash flow tuffs which overlie 


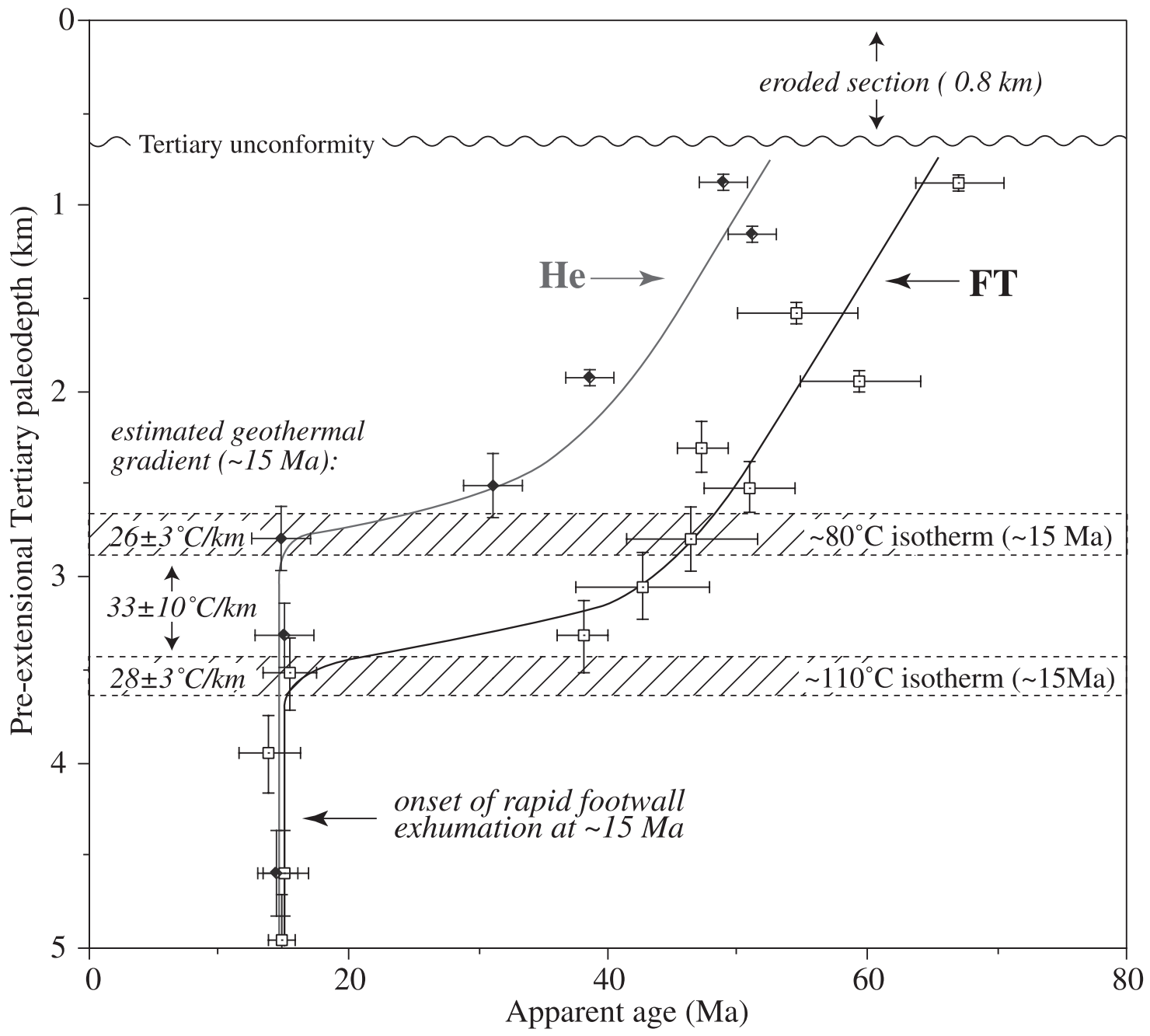

Figure 10. Miocene depth estimates to the inflection points at the base of the PAZ $\left(60^{\circ} \mathrm{C}\right)$ and $\mathrm{HePRZ}$ $\left(40^{\circ} \mathrm{C}\right)$, respectively, allow estimation of geothermal gradients prior to the onset of middle Miocene extension.

the Tertiary erosional unconformity, a feature well exposed throughout the Basin and Range [e.g., Christiansen et al., 1992].

[33] Model runs for samples from a wide range of structural depths were used to estimate the preextensional volcanic and sedimentary overburden above the Tertiary unconformity at the onset of rapid middle Miocene extensional faulting at $\sim 15 \mathrm{Ma}$. The overburden was approximated by plotting preextensional temperature estimates derived from individual model runs against inferred paleodepth below Tertiary unconformity for each sample (Figure 5). In the central Wassuk Range, a line fit through modeled preextensional temperatures of individual samples intercepts the paleodepth axis at $\sim 0.8 \mathrm{~km}$, assuming a $10^{\circ} \pm$ $5^{\circ} \mathrm{C}$ mean annual surface temperature. This estimate is consistent with the average regional thickness of the Lincoln Flat andesite, but was also used with caution because of uncertainties in the calibration of annealing parameters and the large uncertainties and nonuniqueness of individual model runs. The slope of the best fit line through the modeled sample temperatures also allows the estimation of a preextensional paleogeothermal gradient of $27^{\circ} \pm 3{ }^{\circ} \mathrm{C} / \mathrm{km}$, which is in good agreement with estimates derived from other thermochronological lines of evidence.

[34] Model results of partially annealed fission track samples from the deepest structural levels along the active range front on the east flank of the Wassuk Range (Figure 12) suggest a distinct three-stage thermal history characterized by rapid cooling and exhumation in middle Miocene time, a period of relative tectonic quiescence and near isothermal behavior, and a more recent episode of renewed extensional faulting starting at $\sim 4 \mathrm{Ma}$ (Figure 12). The modeling also suggests that the well-documented large-magnitude Miocene extensional event was limited to a relatively short time period between $15 \mathrm{Ma}$ and $\sim 12 \mathrm{Ma}$, indicating that fault slip, exhumation, and westward tilting of these crustal fault blocks was quite rapid. Renewed post-Miocene cooling suggested by the fission track modeling results is in 


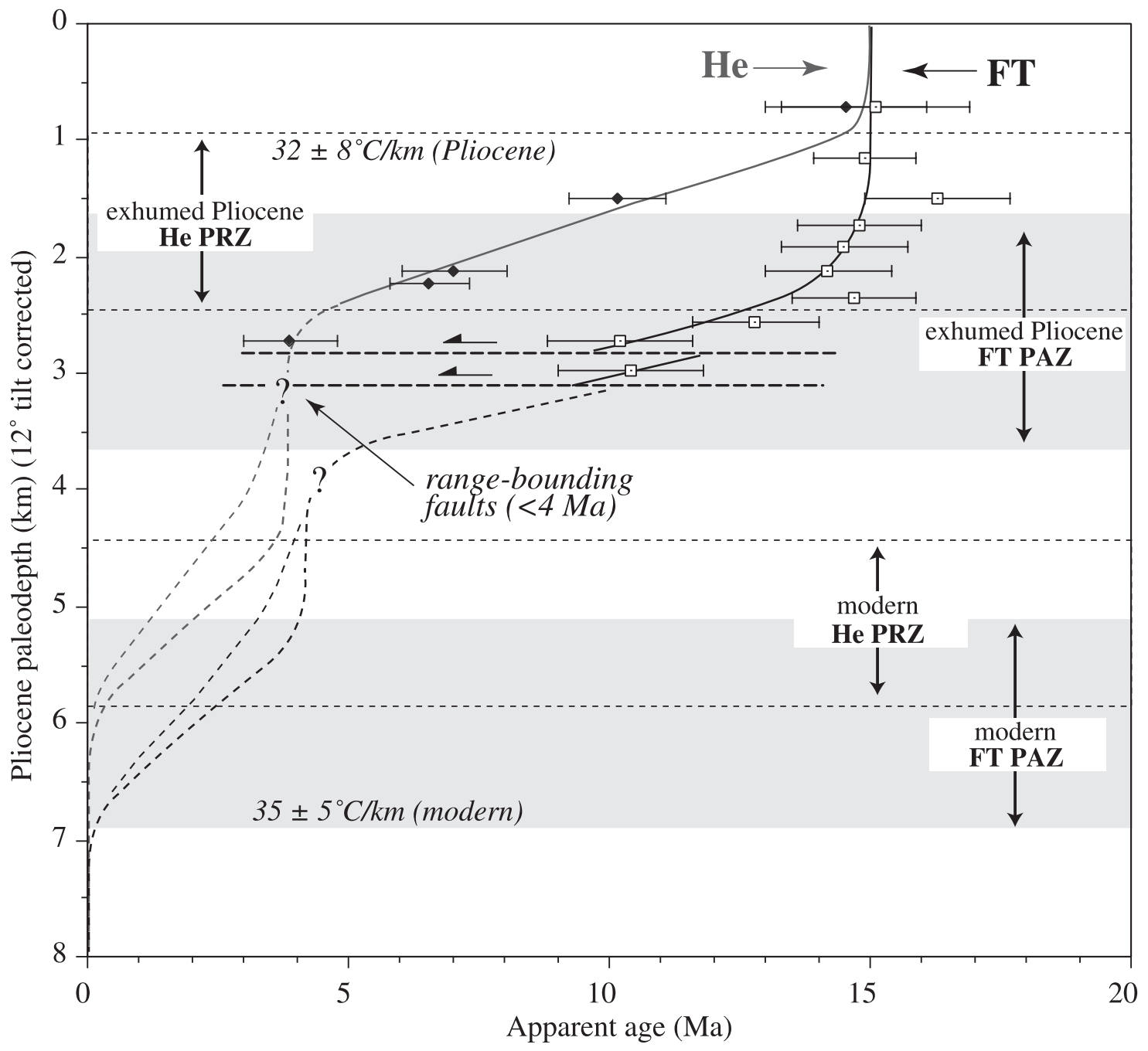

Figure 11. Apatite fission track and (U-Th)/He thermochronological data from the eastern flank of the central Wassuk Range. The data are plotted against Pliocene paleodepth based on $12^{\circ}$ westward tilted $\sim 7 \mathrm{Ma}$ volcanic rocks. The position of the Pliocene paleosurface is estimated using a geothermal gradient $\left(32^{\circ} \pm 8^{\circ} \mathrm{C} / \mathrm{km}\right)$ deduced from the position of the inflection points that define the base of the PAZ and the HePRZ and the structural width of the HePRZ. The inflection point in the (U-Th)/He curve and the predicted inflection in the apatite fission track curve (based on geothermal gradient) suggest $\sim 4 \mathrm{Ma}$ as the onset of significant Pliocene-Quaternary range front faulting. The modern geothermal gradient $\left(\sim 35^{\circ} \mathrm{C} / \mathrm{km}\right)$ also allows estimation of the present-day PAZ and the HePRZ.

agreement with Pliocene westward tilting related to faulting along the eastern range front of the Wassuk Range recorded by (U-Th)/He data and $\sim 7 \mathrm{Ma}$ andesite flows. The thermal modeling results also provide additional support for an episodic rather than continuous nature of post-middle Miocene extension in the central Wassuk Range.

\section{Discussion and Conclusions}

[35] Apatite fission track and (U-Th)/He data indicate that the central Wassuk Range has experienced multiple episodes of Neogene extensional deformation in the form of westward fault block tilting about a NNW trending horizontal axis. The apparent age versus paleodepth curves show no offsets or deviations from the theoretically predicted age versus depth patterns, suggesting that the Grey Hills and Wassuk fault blocks are structurally intact, except along the modern range front fault system. Valuable insights into the thermal evolution of the fault blocks in the central Wassuk Range can be gleaned from thermochronological data which constrain the timing of cooling and westward tilting, the local geothermal gradients at the onset of faulting, and important aspects of pretilt and posttilt cooling.

[36] The onset of cooling and exhumation at $\sim 15 \mathrm{Ma}$ is in good agreement with constraints derived from volcanic 

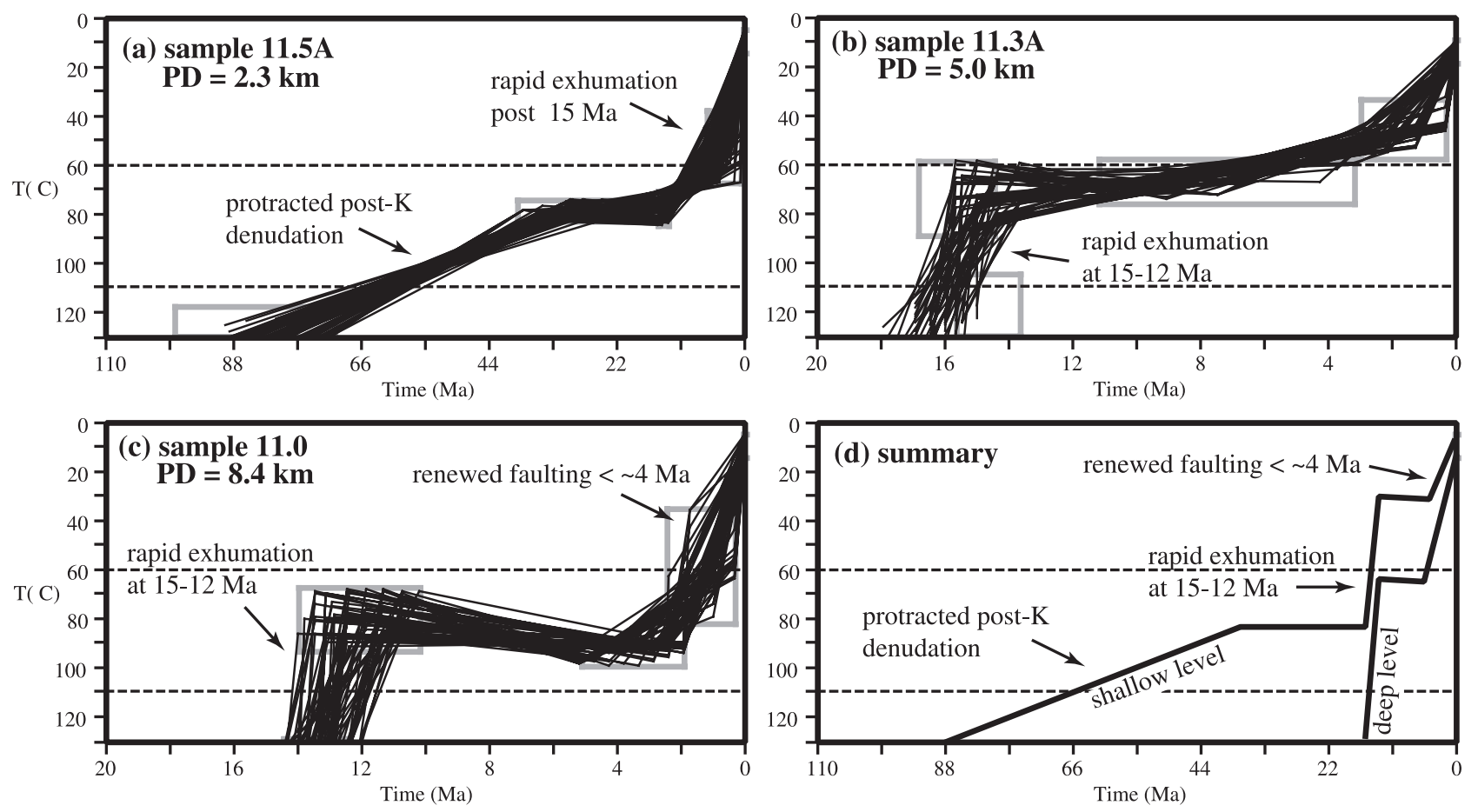

Figure 12. Apatite fission track modeling results for representative samples from the entire range of structural levels, recording a multistage cooling and exhumation history of the central Wassuk Range. See text for detailed description of thermal modeling. (a) Model results for a sample from within the exhumed Miocene PAZ illustrate the protracted post-Cretaceous erosional denudation of the Sierra Nevada $\left(\sim 1^{\circ} \mathrm{C} /\right.$ m.y.) and rapid cooling in the Neogene related to large magnitude crustal extension. (b and c) Model results for samples below the Miocene PAZ and within the Pliocene PAZ clearly demonstrate a two-stage cooling and exhumation history consistent with faulting between $\sim 12$ and $15 \mathrm{Ma}$ and renewed faulting since $\sim 4 \mathrm{Ma}$. (d) Summary diagram of fission track modeling results for samples from different structural levels permit the reconstruction of a complete cooling and exhumation history of the central Wassuk Range since the late Cretaceous to the present.

and sedimentary deposits bracketing the timing of extensional faulting and fault block tilting [Surpless, 1999]. The timing of extensional faulting is similar to that documented in the northern Singatse Range to the west [Proffett, 1977; Proffett and Dilles, 1984; Dilles and Gans, 1995; Surpless et al., 2002]. In the Singatse Range, large-magnitude extension occurred along closely spaced faults $(\sim 1-2 \mathrm{~km})$ immediately following the eruption of 15.0-13.8 Ma hornblende andesite lava flows. High rates of extension continued until sometime before 13.0-12.6 Ma, based on volumetrically minor andesite dikes that crosscut previously active fault surfaces [Dilles and Gans, 1995]. These lines of evidence are in excellent agreement with thermochronological and geologic observations from the central Wassuk Range which independently constrain the timing of rapid middle Miocene extensional faulting to a period beginning at $\sim 15 \mathrm{Ma}$ and ending by $\sim 12 \mathrm{Ma}$. Extension in both the Singatse Range and the central Wassuk Range caused westward fault block tilts of the order of $\sim 60^{\circ}$ or greater and has exposed large structural sections of the preextensional granitic upper crust. The similarity in timing of magmatism and faulting, magnitude of extension, and structural style of the Singatse and Wassuk Ranges support the hypothesis that these now geographically separate areas experienced a single, large-magnitude extensional event that occurred across both of these ranges in the middle Miocene [Proffett, 1977; Proffett and Dilles, 1984; McIntyre, 1990; Dilles and Gans, 1995].

[37] The causal and temporal relationship between extension and volcanism remains a controversial topic in the Basin and Range province [e.g., Best and Christiansen, 1991; Gans et al., 1989]. Gans and Bohrson [1998] documented volcanism that preceded short-lived episodes of large-magnitude extension in several areas of the Basin and Range province, including the Singatse Range, while synextensional magmatism appears to be effectively suppressed during extensional faulting. This temporal pattern of magmatism and extension is also supported by observations in the central Wassuk Range, where the extrusion of large volumes of hornblende andesite flows immediately preceded extension, while volumetrically significant magmatism is absent during the highest rates of middle Miocene extension.

[38] The geologic and magmatic history of the Wassuk Range suggest that the area was part of the former Sierra Nevada magmatic arc prior to middle Miocene extension 


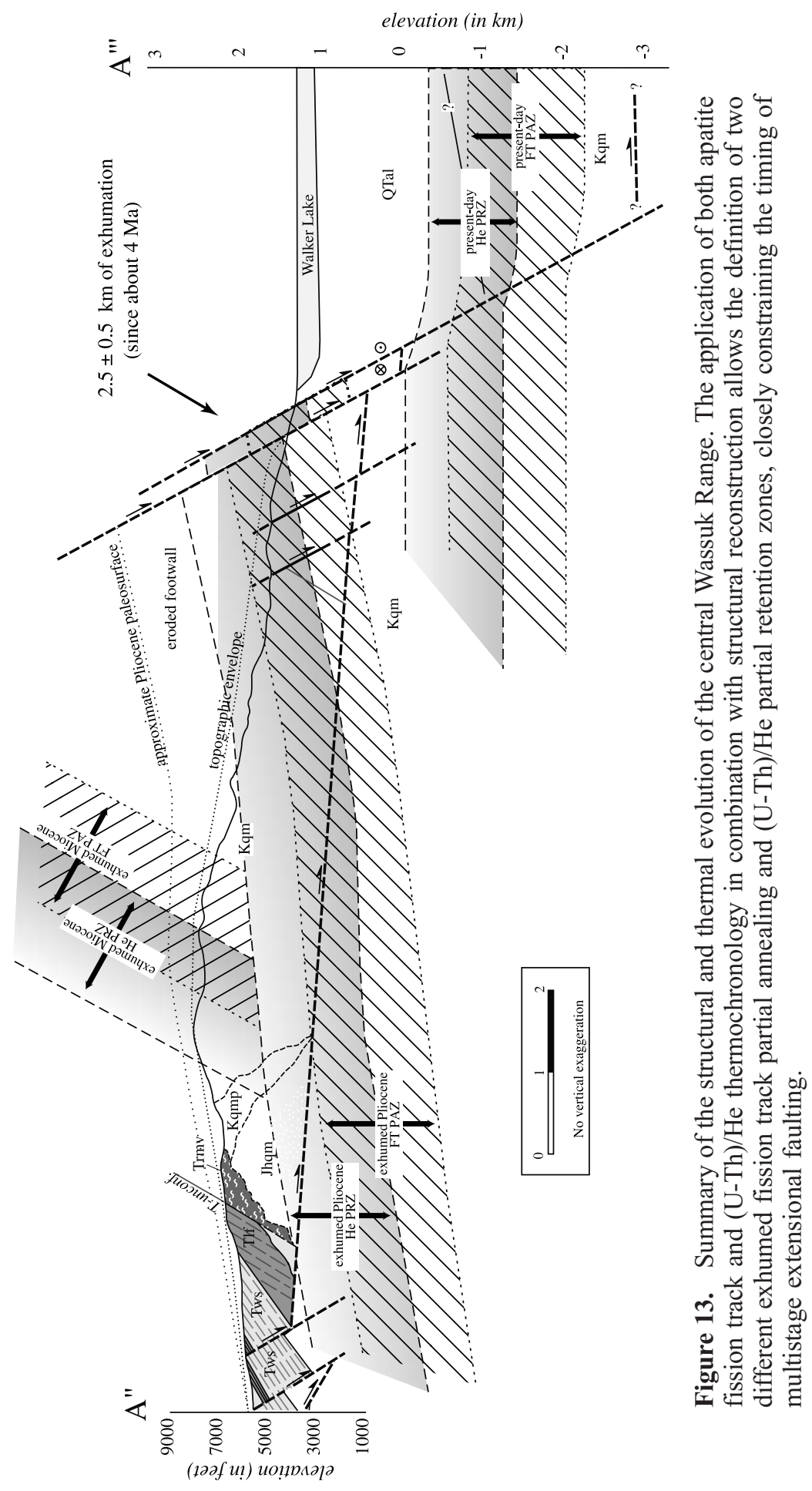


and might have experienced a similar preextensional thermal history [e.g., Dilles and Wright, 1988] (Figure 1). Apatite fission track data from the eastern Sierra Nevada [Dumitru, 1990] suggest a post-Cretaceous geothermal gradient of $10^{\circ} \pm 5^{\circ} \mathrm{C} / \mathrm{km}$, although this low estimate remains controversial [House et al., 1997]. The White Mountains fault block to the south of the Wassuk Range also exhibit a low Miocene preextensional geothermal gradient $\left(15^{\circ} \pm 2^{\circ} \mathrm{C} / \mathrm{km}\right)$ [Stockli et al., 2000], suggesting relatively low post-Cretaceous geothermal gradients in much of the westernmost Basin and Range province. The new thermochronological data presented here are not capable of independently demonstrating such low early Tertiary geothermal gradients for the Wassuk Range. However, under the assumption that the study area was part of the Sierra Nevada and experienced a similar preextensional thermal history with geothermal gradients of $<15^{\circ}-20^{\circ} \mathrm{C} /$ $\mathrm{km}$, our data from the central Wassuk Range indicate an increase in geothermal gradient prior to the onset of middle Miocene extension $\left(27^{\circ} \pm 5^{\circ} \mathrm{C} / \mathrm{km}\right)$. If this were indeed the case, the relatively large volume of preextensional andesitic magmatism would suggest that magmatic heat advection might have played a significant role in increasing geothermal gradients prior to the onset of extension. We speculate that the observed Miocene preextensional geothermal gradient $\left(27^{\circ} \pm 5^{\circ} \mathrm{C} / \mathrm{km}\right)$ might represent a transitional value and imply a concomitant thermal weakening and reduction of the total strength of the crust, prior to the onset of extension.

[39] Following the episode of rapid middle Miocene extension, apatite fission track and (U-Th)/He data indicate a period of much reduced cooling rates and near isothermal conditions which lasted until Pliocene time, with a second major cooling and exhumation event starting at $\sim 4 \mathrm{Ma}$ and continuing to the present day. This later period of extensional deformation has been concentrated along the range bounding fault system on the eastern flank of the Wassuk Range. The thermochronological data from the eastern flank of the central Wassuk Range suggest a Pliocene geothermal gradient of $32^{\circ} \pm 8^{\circ} \mathrm{C} / \mathrm{km}$, which is within error of the present day value of $\sim 35^{\circ} \mathrm{C} / \mathrm{km}$. This observation suggests that the geothermal gradient in and around the central Wassuk Range has remained virtually unchanged since the end of middle Miocene extension. The apparent increase in geothermal gradient from the time prior to middle Miocene extension $\left(\sim 27^{\circ} \mathrm{C} / \mathrm{km}\right)$ to Mio-Pliocene time $\left(\sim 32^{\circ} \mathrm{C} / \mathrm{km}\right)$ can be in part attributed to advective heating due to crustal thinning and coeval mafic underplating beneath the western Basin and Range province [e.g., Jarchow and Thompson, 1993].

[40] By constraining the Pliocene geothermal gradient, the younger thermochronological samples from the east flank of the central Wassuk Range together with the MioPliocene volcanic rocks allow a rough approximation of a Pliocene paleosurface profile across the range (Figure 13). The position of an approximate paleosurface illustrates the significant volume of rock eroded since the Pliocene and allows an estimation of the post-Pliocene exhumation along the range bounding fault system $(2.5 \pm 0.5 \mathrm{~km})$. It is interesting to note that this exhumation estimate is roughly similar to the thickness of sediments in the adjacent Walker Lake half graben on the basis of gravity data [Plouff, 1987].

[41] The exposure of two distinct fossil partial annealing/retention zones formed by two temporally distinct exhumation events is rather remarkable and demonstrates the power of integrating structural reconstruction with both apatite fission track and (U-Th)/He thermochronology (Figure 13). The combination of thermochronological methods allows a complete temporal and thermal reconstruction, ranging from large-scale extensional deformation to nearsurface tectonic and geomorphologic processes. A combination of factors including the relatively elevated geothermal gradients in the region, the episodic nature of extension, the large magnitude of extension, and excellent footwall exposures across a full range of paleodepths has afforded an extraordinary opportunity to provide detailed thermal information for the evolution of an extensional terrain.

[42] Acknowledgments. This project was supported by NSF grants EAR-9417939 and EAR-9725371 (to E. L. Miller and T. A. Dumitru), Caltech postdoctoral fellowship to D. Stockli, and a Packard fellowship to K. Farley. We would like to thank E. Miller, M. McWilliams, J. Dilles, J. Oldow, and S. Klemperer for stimulating discussions and helpful insights, and B. Wernicke and P. Armstrong for improving the final version of the manuscript.

\section{References}

Best, M. G., and E. H. Christiansen, Limited extension during peak Tertiary volcanism, Great Basin of Nevada and Utah, J. Geophys. Res., 96, 13,50913,528, 1991.

Bingler, E. C., Geologic map of the Shurz quadrangle, Nevada, Nev. Bur. of Mines and Geol., Reno, 1978.

Bryant, B., and C. W. Naeser, The significance of fission-track ages of apatite in relation to the tectonic history of the Front and Sawatch ranges, Colorado, Geol. Soc. Am. Bull., 91, 156-164, 1980.

Christiansen, R. L., R. S. Yeats, S. A. Graham, W. A. Niem, and J. Snavely, Post-Laramide geology of the U.S. Cordilleran region, in The Geology of North America, vol. G3, The Cordilleran Orogen: Conterminous U.S., edited by B. C. Burchfiel, W. Lipman, and M. L. Zoback, pp. 261-406, Geol. Soc. of Am., Boulder, Colo., 1992.

Corrigan, J. D., Inversion of apatite fission track data for thermal history information, J. Geophys. Res., 96, 10,347-10,360, 1991 .

Crowley, K. D., M. Cameron, and R. L. Schaefer, Experimental studies of annealing of etched fission tracks in fluorapatite, Geochim. Cosmochim. Acta, $55,1449-1465,1991$

Dilles, J. H., Cenozoic normal and strike-slip faults in the northern Wassuk Range, western Nevada, in Structure, Tectonics and Mineralization of the Walker Lane: Walker Lane Symposium Proceedings, edited by S. D. Craig, pp. 114-136, Geol. Soc. of Nev., Reno, 1992

Dilles, J. H., and B. Gans, The chronology of Cenozoic volcanism and deformation in the Yerington area, western Basin and Range and Walker Lane, Geol. Soc. Am. Bull., 107, 474-486, 1995.

Dilles, J. H., and J. E. Wright, The chronology of early Mesozoic arc magmatism in the Yerington District of western Nevada and its regional implications, Geol. Soc. Am. Bull., 100, 644-672, 1988.

Dumitru, T. A., Subnormal Cenozoic geothermal gradients in the extinct Sierra Nevada magmatic arc: Consequences of Laramide and post-Laramide shallow-angle subduction, J. Geophys. Res., 95, 49254941, 1990.

Dumitru, T. A., A new computer-automated microscope stage system for fission track analysis, $\mathrm{Nucl}$. Tracks Radiat. Meas., 21, 575-580, 1993.

Farley, K. A., R. A. Wolf, and L. T. Silver, The effects of long alpha-stopping distances on (U-Th)/He dates, Geochim. Cosmochim. Acta, 60, 42234230, 1996.

Farley, K. A., M. E. Rusmore, and S. W. Bogue, Post$10 \mathrm{Ma}$ uplift and exhumation of the northern Coast Mountains, British Columbia, Geology, 29, $99-$ 102, 2001. 
Fitzgerald, G., and A. J. W. Gleadow, New approaches in fission track geochronology as a tectonic tool: Examples from the Transantarctic Mountains, Nucl. Tracks Radiat. Meas., 17, 351-357, 1990.

Fitzgerald, G., J. E. Fryxell, and B. P. Wernicke, Miocene crustal extension and uplift in southeastern Nevada: Constraints from fission track analysis, Geology, 19, 1013-1016, 1991.

Foster, D. A., and B. E. John, Quantifying tectonic exhumation in an extensional orogen with thermochronology: Examples from the southern Basin and Range Province, in Exhumation Processes. Normal Faulting, Ductile Flow and Erosion edited by U. Ring et al., Geol. Soc. Spec. Publ., 154, $343-$ 364, 1999.

Foster, D. A., T. M. Harrison, C. F. Miller, and K. A Howard, The ${ }^{40} \mathrm{Ar} /{ }^{39} \mathrm{Ar}$ thermochronology of the eastern Mojave Desert, California, and adjacent western Arizona with implications for the evolution of metamorphic core complexes, J. Geophys. Res., 95, 20,005-20,024, 1990

Foster, D. A., D. S. Miller, and C. F. Miller, Tertiary extension in the Old Woman Mountains area, California: Evidence from apatite fission-track analysis, Tectonics, 10, 875-886, 1991

Foster, D. A., K. A. Howard, and B. E. John, Thermochronological constraints on the development of metamorphic core complexes in the lower Colorado River area, in Eighth International Conference on Geochronology, Cosmochronology, and Isotope Geology, edited by M. A. Lanphere, G. B. Dalrymple, and B. D. Turrin, U.S. Geol. Surv. Circ., 1107, 103 pp., 1994.

Galbraith, R. F., On statistical models for mixed fission track ages, Nucl. Tracks Radiat. Meas., 13, 471 478, 1981 .

Galbraith, R. F., and G. M. Laslett, Statistical model for mixed fission track ages, Nucl. Tracks Radiat Meas., 21, 459-470, 1983.

Gallagher, K., Evolving temperature histories from apatite fission-track data, Earth Planet. Sci. Lett., 136, 421-443, 1995.

Gans, B., and W. A. Bohrson, Suppression of volcanism during rapid extension in the Basin and Range Province, United States, Science, 279, 66-68, 1998.

Gans, B., G. A. Mahood, and L. Schermer, Synextensional magmatism in the Basin and Range province: A case study from the eastern Great Basin, Geol. Soc. Am. Spec. Pap., 53 pp., 1989

Gans, B., E. L. Miller, R. Brown, G. Housman, and G. $\mathrm{S}$. Lister, Assessing the amount, rate, and timing of tilting in normal fault blocks: A case study of tilted granites in the Kern-Deep Creek Mountains, Utah, Mem. Geol. Soc. Am., 23, 28 pp., 1991.

Glazner, A. F., and J. M. Bartley, Timing and tectonic setting of Tertiary low-angle normal faulting and associated magmatism in the southwestern United States, Tectonics, 3, 385-396, 1984

Gleadow, A. J. W., and G. Fitzgerald, Uplift history and structure of the Transantarctic Mountains: Aew evidence from fission track dating of basement apatites in the Dry Valleys area, southern Victoria Land, Earth Planet. Sci. Lett., 82, 1-14, 1987.

Gleadow, A. J. W., I. R. Duddy, F. Green, and J. F. Lovering, Confined fission track lengths in apatite: A diagnostic tool for thermal history analysis, Contrib. Mineral. Petrol., 94, 405-415, 1986.

Green, F., A new look at statistics in fission track dating, Nucl. Tracks Radiat. Meas., 5, 77-86, 1981.

Green, F., I. R. Duddy, A. J. W. Gleadow, and J. F.
Lovering, Apatite fission-track analysis as a paleotemperature indicator for hydrocarbon exploration, in Thermal History of Sedimentary Basins: Method and Case Histories, edited by N. D. Naeser and T. H. McCulloh, pp. 181-195, Springer-Verlag, New York, 1989a.

Green, F., I. R. Duddy, G. M. Laslett, K. A. Hegarty, A J. W. Gleadow, and J. F. Lovering, Thermal annealing of fission-tracks in apatite, 4, Quantitative modeling techniques and extension to geological time scales, Chem. Geol., 79, 155-182, 1989.

House, M. A., B. P. Wernicke, K. A. Farley, and T. A. Dumitru, Cenozoic thermal evolution of the central Sierra Nevada, California, from (U-Th)/He thermochronometry, Earth Planet. Sci. Lett., 151, $167-$ 179, 1997.

House, M. A., K. A. Farley, and B. P. Kohn, An empirical test of helium diffusion in apatite: Borehole data from the Otway Basin, Australia, Earth Planet. Sci. Lett., 170, 463-474, 1999.

Howard, K. A., and D. A. Foster, Thermal and unroofing history of a thick, tilted Basin-and-Range crusta section in the Tortilla Mountains, Arizona, J. Geophys. Res., 101, 511-522, 1996

Hurford, A. J., and F. Green, The zeta calibration of fission track dating, Chem. Geol., C, 41, $285-$ 317, 1983

Jarchow, C. M., and G. A. Thompson, Seismic evidence for active magmatism beneath the Basin and Range Province, Western United States, J. Geophys. Res. 98, 22,095-22,108, 1993.

Lachenbruch, A. H., and J. H. Sass, Models of an extending lithosphere and heat flow in the Basin an Range province, in Cenozoic Tectonics and Regional Geophysics of the Western Cordillera, edited by R. B. Smith and G. P. Eaton, Mem. Geol. Soc. Am. $152,209-250,1980$

Laslett, G. M., W. S. Kendall, A. J. W. Gleadow, and I R. Duddy, Bias in the measurements of fission track length distributions, Nucl. Tracks Radiat. Meas., 6 , $79-85,1982$

Laslett, G. M., P. F. Green, I. R. Duddy, and A. J. W Gleadow, Thermal annealing of fission tracks in apatite, 2, A quantitative analysis, Chem. Geol. $65,1-13,1987$.

Mancktelow, N. S., and B. Grasemann, Time-dependent effects of heat advection and topography on cooling histories during erosion, Tectonophysics, 270, 167 195, 1997.

McIntyre, J., Late Cenozoic structure of the Centra Wassuk Range, Mineral County, Nevada, M. S. thesis, 176 pp., Oregon State Univ., Corvallis, 1990.

Miller, E. L., T. A. Dumitru, R. Brown, and B. Gans, Rapid Miocene slip on the Snake Range-Deep Creek Range fault system, east-central Nevada, Geol. Soc. Am. Bull., 111, 886-905, 1999.

Moore, J. G., and N. L. Archbold, Geology and mineral deposits of Lyon, Douglas, and Ormsby counties, Nevada, with a section on industrial minerals, 44 pp., Nev. Bur. of Mines and Geol., Reno, 1969

Naeser, C. W., Fission track dating and geological annealing of fission tracks, in Lectures in Isotop Geology, edited by E. Jäger and J. C. Hunziker, pp. 154-169, Springer-Verlag, New York, 1979

Oldow, J. S., Late Cenozoic displacement partitioning in the northwestern Great Basin, in Structure, Tectonics and Mineralization of the Walker Lane: Walker Lane Symposium Proceedings, edited by S. D. Craig, pp. 17-52, Geol. Soc. of Nev., Reno, 1992.
Plouff, D., Bouguer gravity anomaly and isostatic residual gravity maps of the Walker Lake 1 degrees by 2 degrees Quadrangle, California and Nevada, U.S Geol. Surv. Misc. Field Stud. Map MF-1382-E, 1987.

Proffett, J. M., Jr., Cenozoic geology of the Yerington District, Nevada, and implications for the nature and origin of Basin and Range faulting, Geol. Soc. Am Bull., 88, 247-266, 1977.

Proffett, J. M., and J. H. Dilles, Geologic map of the Yerington district, Nevada, Nev. Bur. of Mines and Geol., Reno, 1984

Proffett, J. M., and B. H. Proffett, Stratigraphy of the Tertiary ash-flow tuffs in the Yerington district, $\mathrm{Ne}$ vada, Nev. Bur. Mines Geol. Rep, 28, 1976.

Reiners, W., R. Brady, K. A. Farley, J. E. Fryxell, B. Wernicke, and D. Lux, Helium and argon thermochronometry of the Gold Butte Block, South Virgin Mountains, Nevada, Earth Planet. Sci. Lett., 178, $315-326,2000$

Stewart, J. H., Regional tilt patterns of late Cenozoic basin-range fault blocks, western United States, Geol. Soc. Am. Bull., 91, 460-464, 1980.

Stewart, J. H., Walker Lane Belt, Nevada and California•An overview, in Structure, Tectonics and Mineralization of the Walker Lane: Walker Lane Symposium Proceedings, edited by S. D. Craig, pp. 1-16, Geol. Soc. of Nev., Reno, 1992.

Stewart, J. H., et al., Geologic map of the Walker Lake $1^{\circ} \times 2^{\circ}$ quadrangle, California-Nevada, U.S. Geol. Surv. Misc. Field Stud. Map, 1984.

Stockli, D. F., Regional timing and spatial distribution of Miocene extension in the northern Basin and Range Province, Ph. D. thesis, 239 pp., Stanford Univ., Stanford, Calif., 1999.

Stockli, D. F., K. A. Farley, and T. A. Dumitru, Calibration of the apatite (U-Th)/He thermochronomete on an exhumed fault block, White Mountains, California, Geology, 28, 983-986, 2000

Surpless, B. E., A structural, magmatic, and thermochronological study of the central Wassuk Range, western Nevada, Ph. D. thesis, 225 pp., Stanford Univ., Stanford, Calif., 1999

Wernicke, B. P., Cenozoic extensional tectonics of the U. S. Cordillera, in The Geology of North America, vol. G3, The Cordilleran Orogen: Conterminous U.S., edited by B. C. Burchfiel, W. Lipman, and M. L. Zoback, pp. 553-581, Geol. Soc. of Am., Boulder, Colo., 1992.

Wolf, R. A., K. A. Farley, and L. T. Silver, Assessment of (U-Th)/He thermo-chronometry: The low-temperature history of the San Jacinto Mountains, California, Geology, 25, 65-68, 1997.

Wolf, R. A., K. A. Farley, and D. M. Kass, Modeling of the temperature sensitivity of the apatite (U-Th)/He thermochronometer, Chem. Geol., 148, 105-114, 1998

T. A. Dumitru and B. E. Surpless, Department of Geological and Environmental Science, Stanford University, Stanford, CA 94305-2115, USA. (trevor@ pangea.stanford.edu; bsurpless@bcp.org)

K. A. Farley, Division of Geological and Planetary Sciences, California Institute of Technology, Pasadena, CA 91125, USA. (farley@gps.caltech.edu)

D. F. Stockli, Department of Geology, University of Kansas, 1475 Jayhawk Boulevard, 120 Lindley Hall, Lawrence, KS 66045-7613, USA. (stockli@ku.edu) 